Article

\title{
An Increase of Abundance and Transcriptional Activity for Acinetobacter junii Post Wastewater Treatment
}

\author{
Muhammad Raihan Jumat ${ }^{1}{ }^{(\mathbb{D})}$, Muhammad Fauzi Haroon ${ }^{2}$, Nada Al-Jassim ${ }^{1}$, Hong Cheng ${ }^{1}$ and \\ Pei-Ying Hong ${ }^{1, *}$ (iD \\ 1 Water Desalination and Reuse Center (WDRC), Biological and Environmental Science \& Engineering \\ Division (BESE), King Abdullah University of Science and Technology (KAUST), Thuwal 23955-6900, \\ Saudi Arabia; raihan.jumat@kaust.edu.sa (M.R.J.); nada.aljassim@kaust.edu.sa (N.A.-J.); \\ hong.cheng@kaust.edu.sa (H.C.) \\ 2 Department of Organismic and Evolutionary Biology, Harvard University, Cambridge, MA 02138, USA; \\ fauziharoon@gmail.com \\ * Correspondence: peiying.hong@kaust.edu.sa; Tel.: +966-(0)-808-2218
}

Received: 29 January 2018; Accepted: 28 March 2018; Published: 6 April 2018

\begin{abstract}
A membrane bioreactor (MBR)-based wastewater treatment plant (WWTP) in Saudi Arabia is assessed over a five-month period in 2015 and once in 2017 for bacterial diversity and transcriptional activity using metagenomics, metatranscriptomics and real time quantitative polymerase chain reaction (RT-qPCR). Acinetobacter spp. are shown to be enriched in the chlorinated effluent. Members of the Acinetobacter genus are the most abundant in the effluent and chlorinated effluent. At the species level, Acinetobacter junii have higher relative abundances post MBR and chlorination. RNA-seq analysis show that, in A. junii, 288 genes and 378 genes are significantly upregulated in the effluent and chlorinated effluent, respectively, with 98 genes being upregulated in both. RT-qPCR of samples in 2015 and 2017 confirm the upregulation observed in RNA-seq. Analysis of the 98 genes show that majority of the upregulated genes are involved in cellular repair and metabolism followed by resistance, virulence, and signaling. Additionally, two different subpopulations of A. junii are observed in the effluent and chlorinated effluent. The upregulation of cellular repair and metabolism genes, and the formation of different subpopulations of $A$. junii in both effluents provide insights into the mechanisms employed by A. junii to persist in the conditions of a WWTP.
\end{abstract}

Keywords: Acinetobacter junii; wastewater treatment plant; antibiotic resistance; metal resistance genes; persistence

\section{Introduction}

It is predicted that, by 2050, many countries worldwide will bear the brunt of global water scarcity [1]. To relieve the pressure on finite sources of fresh water, treated wastewater has been purported as an alternative source. If adequately treated, recycled wastewater may serve for irrigation and other non-potable uses. Guidelines are typically put in place in most countries to guide the level of treatment required for the wastewaters prior to reuse. For example, Saudi Arabia requires a fecal coliform count of $<1000 \mathrm{CFU} / 100 \mathrm{~mL}$ for reuse in restricted irrigation or $<2.2 \mathrm{CFU} / 100 \mathrm{~mL}$ for unrestricted irrigation [2]. In general, most studies show that wastewater treatment plants (WWTPs) are successful in reducing bacterial diversity and abundance [3-5]. However, WWTPs have repeatedly been shown to be hotbeds of antibiotic resistance genes (ARGs), antibiotic-resistant bacteria (ARB) and pathogen enrichment [6-8]. In particular, virulent and resistant pathogens are constantly detected 
in the effluents of WWTPs [4,9-11]. The subsequent dissemination of pathogens from WWTPs is a significant cause of concern for public health.

To circumvent the problems associated with conventional WWTPs, WWTPs worldwide have recently coupled microfiltration or ultrafiltration membranes to their activated sludge processes. This configuration is typically referred to as the aerobic membrane bioreactor (MBR). The membrane separates biomass from wastewater by filtration, resulting in higher water quality [12]. MBRs are typically operated with a longer sludge retention time compared to the conventional activated sludge processes. This results in lower sludge production rates due to biodegradation of the biomass and lower growth yield, likely arising from the depletion of available substrates within the sludge biomass. The effluent from the MBR is then subjected to disinfection, typically by chlorine, which inactivates any viable microorganisms that may be present $[13,14]$. Chlorine is an oxidizing agent and achieves its disinfection efficacy by oxidizing nucleic acids, proteins and destabilizing cell walls of microorganisms present in the WWTP effluent [15]. Chlorine further reacts with water to form hypochlorous acid and hypochlorite, which is a type of reactive oxygen species (ROS) that can generate oxidative stress towards microorganisms. Oxidative stress can further trigger the formation of intracellular ROS which are highly reactive molecules that can interfere with normal functions of bacteria [16-18]. Collectively, the MBR and chlorination were shown to be responsible in reducing the microbial load and diversity of wastewater in a WWTPs situated in Saudi Arabia [19,20], possibly due to imposition of harsh conditions that do not favor bacterial proliferation and growth.

However, several antibiotic-resistant strains, which were absent in the influent, were detected in the effluent and chlorinated effluent [4]. Among these were members of the Acinetobacter genus which were found to be resistant to ampicillin, kanamycin, erythromycin, tetracycline and chloramphenicol (Tables S1 and S2). Similarly, antibiotic-resistant Acinetobacter spp. have been previously isolated from other WWTPs, suggesting that antibiotic resistance confers tolerance to the harsh WWTP conditions [21,22]. An earlier study also showed that Acinetobacter spp. undergo a shift in metabolism in activated sludge, which might be another mechanism adopted by this genus to survive the wastewater treatment process [23]. These studies, although enlightening, used conventional polymerase chain reaction (PCR), which is skewed towards known genes and dependent on primer design, to detect for changes in Acinetobacter spp. activity.

Acinetobacter spp. are Gram negative, coccobacilli bacteria belonging to the Moraxellaceae family. Acinetobacter spp. have been shown to thrive in hospital settings, being responsible for up to $9 \%$ of nosocomial infections [24]. Among members of this genus, Acinetobacter junii has been shown to be an opportunistic pathogen causing disease in individuals with known malignancies, or in those who had received prior antibiotic treatment or invasive procedures. The symptoms of infection with $A$. junii include septicemia, bacteremia, empyema, peritonitis and keratitis [25-27]. Members of this genus have also been shown to facilitate uptake of ARGs from E. coli through horizontal gene transfer at higher rates than other studied bacteria [28].

Given the ubiquitous detection of members of the genera Acinetobacter in diverse environments including activated sludge [29], different stages of WWTPs [30], hospital effluent [31], clinical samples [32] and environmental samples [21,33,34], we hypothesize that Acinetobacter spp. may utilize several strategies to facilitate their survival and persistence. In this study, we further utilized A. junii, which was detected to be ubiquitously present in samples collected from different stages of the WWTP, as a model bacterium to address this hypothesis. It was hypothesized that $A$. junii upregulates specific genes to allow for its survival in the harsh environments of a WWTP. To determine this, $A$. junii from different stages of a WWTP serving a university campus is studied by RNA-seq. This overcomes the biasness of PCR and captures global changes in transcriptional activity of Acinetobacter spp. before and after wastewater treatment. Results indicate an increase in relative abundance of Acinetobacter spp. down the treatment process with a concomitant increase in transcriptional activity. Majority of the upregulated genes correspond to cellular resistance and metabolism. Other upregulated genes encode 
for metal-resistance, efflux pumps and mobility proteins, all which have been implicated in conferring antibiotic resistance and increased survivability in harsh environmental conditions.

\section{Materials and Methods}

\subsection{Wastewater Sampling}

A WWTP located on the campus of King Abdullah University of Science and Technology (KAUST), Thuwal, Saudi Arabia was sampled for the purposes of this study. The operation of the WWTP has been previously described [19]. Briefly, large screens prevent entry of insoluble and bulky solids into the primary clarifier. Wastewater was retained inside the primary clarifier for ca. $3 \mathrm{~h}$ to allow settle-able suspended solids to settle at the bottom of clarifier in the presence of coagulants. The clarified sewage then undergoes biological treatment in an anoxic sludge tank. A second oxic sludge tank is equipped with a $0.4 \mu \mathrm{m}$ pore sized-submerged microfiltration membrane which forms the membrane bioreactor. Both sludge tanks have a total capacity of $1600 \mathrm{~m}^{3}$. Mixed liquor suspended solids (MLSS) concentration of the activated sludge was maintained at $16 \mathrm{~g} / \mathrm{L}$. The membranes were operated at a flux of $15.5 \mathrm{~L} /\left(\mathrm{m}^{2} \cdot \mathrm{h}\right)$ with a trans-membrane pressure below $20 \mathrm{kPa}$. These membranes have been cleaned monthly with $5 \% \mathrm{ClO}^{-}$solution throughout their 7 years of operation. The MBR is operated at a 4-h hydraulic retention time and a 40-day sludge retention time (SRT). The MBR produces $4000 \mathrm{~m}^{3}$ of effluent daily. Up to $60 \mathrm{~L}$ of the MBR effluent was sampled each time, and referred to as "effluent" throughout this study. In this WWTP, MBR effluent is stored in an $8500 \mathrm{~m}^{3}$ holding tank and mixed with $400 \mathrm{~m}^{3} / \mathrm{d}$ of blow-down from a nearby seawater cooling tower [20]. This mixed stream is disinfected with a free chlorine residual of $0.5 \mathrm{mg} / \mathrm{L}$ at a contact time of $2.5 \mathrm{~h}$, thrice daily resulting in a contact time (CT) of $75 \mathrm{mg} \cdot \mathrm{min} / \mathrm{L}$. While Saudi Arabia currently does not have any regulations on the minimum required chlorine dose for disinfection, the operators voluntarily chose to adhere to the recommended minimum value of $30 \mathrm{mg} \cdot \mathrm{min} / \mathrm{L}$ as suggested by the US-EPA for disinfection of waters for reuse purposes [35]. The chlorinated water from this holding tank was sampled and referred to as "chlorinated effluent" throughout this study. Influent, effluent and chlorinated effluent were sampled in July 2015, October 2015, November 2015 and October 2017. For each sampling expedition, 20 L of influent and $60 \mathrm{~L}$ of both effluents were collected.

\subsection{Tangential Flow Filtration}

To concentrate any microbial matter, each wastewater sample was passed through a tangential flow filtration (TFF) system fitted with a T-Series cassette with a $100 \mathrm{kDa}$ cut-off, which should retain any matter $>0.005 \mu \mathrm{m}$ (Pall Corporation, Port Washington, NY, USA). The recovery efficiency of the TFF system was previously described using enterovirus as model contaminant, with an efficiency ranging from $47.8 \%$ to $86.9 \%$ [19]. Influent samples were centrifuged at $7500 \times g$ for $10 \mathrm{~min}$ to obtain $12 \mathrm{~L}$ of clarified influent prior to TFF concentration. Samples were concentrated to $5 \mathrm{~mL}$ of retentate. These concentrated samples were denoted as Influent-Retentate, Effluent-Retentate and Chlorinated Effluent-Retentate. To ensure recovery of microbial matter that was adhered to the cassette, the system was washed with $50 \mathrm{~mL}$ of $1 \times$ Phosphate Buffered Saline (PBS) containing $0.01 \%$ Tween 60 (Wash Buffer). The wash buffer was recirculated through the system several times before it was concentrated to $5 \mathrm{~mL}$. These samples are denoted as Influent-Wash, Effluent-Wash and Chlorinated Effluent-Wash. Each of these concentrated samples were stored in $-80^{\circ} \mathrm{C}$ prior to nucleic acid extraction. The filter was washed with $0.1 \mathrm{~N} \mathrm{NaOH}$ between samples, as per manufacturer's instructions.

\subsection{Nucleic Acid Extraction and Metagenomics Sequence Analysis}

DNA and RNA were extracted from equal volumes of the retentate and wash concentrates using the DNeasy Blood and Tissue and RNeasy Midi kits (Qiagen, Hilden, Germany), respectively. Concentrations of the extracted DNA and RNA were quantified using the Qubit 2.0 fluorometer (Thermo Fisher Scientific, Carlsbard, CA, USA). To obtain $1 \mu \mathrm{g}$ of DNA and RNA for metagenomic 
and transcriptomic analysis, DNA and RNA extracts were pooled from July 2015, October 2015 and November 2015 samples. DNA libraries were constructed using the TruSeq DNA LT kit and sequenced by the HiSeq2000 system (Illumina, San Diego, CA, USA). RNA libraries were generated by using the TruSeq Stranded mRNA plus Ribo-Zero Epidemiology kit and sequenced by the Illumina NextSeq 500 system. For quality control, $1 \mu \mathrm{L}$ of the resultant libraries was loaded onto an Agilent Technologies 2100 Bioanalyzer (Santa Clara, CA, USA). All the sequenced samples yielded a single band at approximately $260 \mathrm{bp}$. All sequencing reactions were carried out at the KAUST Bioscience Core Laboratory. Raw metagenomic reads were trimmed using Trimmomatic v.0.3.2 [36]. Trimmed reads from each sample were concatenated together. To profile the metagenomes for the most abundant genus among samples collected throughout the WWTP, MetaPhlAn v2.0 [37] was performed using default parameters. Output tables were merged together using "merge_metaphlan_tables.py" and heat maps were created using "metaphlan_hclust_heatmap.py". Initial results of this analysis show a large proportion of the assembled contigs belonging to the species Acinetobacter junii. To further characterize A. junii down the treatment process of this WWTP, RNA-seq analysis was carried out as described below.

RNA-seq data were further analyzed by CLC Genomics Workbench version 8.0.1 from CLC Bio (Cambridge, MA, USA). The complete genome of $A$. junii strain 65 was downloaded from NCBI GenBank (accession number NZ_CP019041.1). RAST annotated genomic DNA sequences were used as reference to map the RNA-seq. Reads were only assembled if the fraction of the read which aligned to the reference genome was greater than 0.9 and if the read matched other regions of the reference genome at fewer than 10 nucleotide positions. Mapped RNA-seq files were only considered if statistically significant $(p<0.05)$ according to the Baggerly proportion-based test [38]. Fold changes of gene expression were calculated with reference to RNA expression in the influent wastewater samples. Only genes with a fold change of more than 2 or less than -2 were considered as significantly upregulated or downregulated, respectively. All sequencing data generated for this study were deposited in the European Nucleotide Archive (ENA) under study accession number PRJEB15519.

\section{4. cDNA Synthesis}

RNA extracted from the wastewater samples were used as template to synthesize complementary DNA (cDNA) for confirmatory qRT-PCR experiments. cDNA was synthesized according to Invitrogen's SuperScript III First-Strand Synthesis for RT-PCR. Briefly, each $6 \mu \mathrm{L}$ of RNA sample was incubated with $1 \mu \mathrm{L}$ of random hexamers and $1 \mu \mathrm{L}$ of Annealing Buffer at $65^{\circ} \mathrm{C}$ for $5 \mathrm{~min}$. The tubes were incubated on ice for $1 \mathrm{~min}$ followed by the addition of $10 \mu \mathrm{L}$ of $2 \times$ First-Strand Reaction Mix and $2 \mu \mathrm{L}$ of SuperScript III/RNaseOUT Enzyme mix. The samples were incubated at $25{ }^{\circ} \mathrm{C}$ for $10 \mathrm{~min}, 50{ }^{\circ} \mathrm{C}$ for $50 \mathrm{~min}$ and terminated at $85^{\circ} \mathrm{C}$ for $5 \mathrm{~min}$. The resulting cDNA was stored at $-20{ }^{\circ} \mathrm{C}$, prior to RT-qPCR.

\section{5. $R T-q P C R$}

RT-qPCR was employed to confirm the upregulations observed in the RNA-seq. Primers were designed for 16 of the genes showing significant upregulation in either or both effluents. Table S3 lists the gene names, primer sequences and gene categorization (Table S3). qPCR standards were amplified from lab grown A. junii strains (DSMZ 14968, 1532). PCR products were cloned into PCR2.1 vectors (Thermo Fisher Scientific, Carlsbad, CA, USA). Plasmids carrying the PCR products were extracted from transformed TOP10 competent cells (Thermo Fisher Scientific, Carlsbad, CA, USA) by using PureYield ${ }^{\mathrm{TM}}$ Plasmid Miniprep System (Promega, Madison, WI, USA). Plasmids were sent to the KAUST Genomics Core Lab for Sanger sequencing to determine the presence of the right primer sequences. Plasmid copy numbers were then determined based on the concentration, insert and vector sizes. Plasmids were subsequently diluted from $10^{2}$ to $10^{8}$ copies $/ \mu \mathrm{L}$ to attain 8-points qPCR standard curves for each gene. Quantities of gene expression were calculated by the relative standard curve method. RT-qPCR were carried out using $10 \mu \mathrm{L}$ of Applied Biosystsems' Fast SYBR ${ }^{\mathrm{TM}}$ Green 
Master Mix (Thermo Fisher Scientific, Carlsbad, CA, USA), $0.4 \mu \mathrm{L}$ of each primer $(10 \mu \mathrm{M}), 8.2 \mu \mathrm{L}$ of molecular-biology grade water and $1 \mu \mathrm{L}$ of template. RT-qPCR was performed using Applied Biosystem ${ }^{\circledR} 7900$ HT Fast Real-Time OCR system with 96-well block module (Thermo Fisher Scientific, Carlsbad, CA, USA). A melting curve analysis was performed with a dissociation cycle that included an increment of temperature from 60 to $95^{\circ} \mathrm{C}$, at an interval of $0.5^{\circ} \mathrm{C}$ for $5 \mathrm{~s}$. After optimization, copy numbers of the gene were determined and normalized against $r p o B$ gene expression.

\subsection{ICP-MS}

The metal content $\left({ }^{24} \mathrm{Mg},{ }^{27} \mathrm{Al},{ }^{47} \mathrm{Ti},{ }^{53} \mathrm{Cr},{ }^{55} \mathrm{Mn},{ }^{56} \mathrm{Fe},{ }^{57} \mathrm{Fe},{ }^{59} \mathrm{Co},{ }^{60} \mathrm{Ni},{ }^{63} \mathrm{Cu},{ }^{66} \mathrm{Zn},{ }^{90} \mathrm{Zr},{ }^{107} \mathrm{Ag}\right.$, ${ }^{111} \mathrm{Cd},{ }^{202} \mathrm{Hg}$, and ${ }^{208} \mathrm{~Pb}$ ) of October 2017 wastewater samples were measured on an inductively coupled plasma mass spectrometry (ICP-MS) (Agilent 7500). Wastewater samples were filtered through $0.22 \mu \mathrm{m}$ Whatman ${ }^{\mathrm{TM}}$ Puradisc 23-mm syringe filters (GE Healthcare, Little Chalfort, Buckinhamshire, UK) prior to measurement. Measurements were made against commercially available standards at 0, 1, 5, 10, 50 and 100 parts per billion in 2\% $\mathrm{HNO}_{3}$ (CMS-3, CMS-4, CMS-5, and MSHG) (Inorganic Ventures, Christiansburg, VA, USA). Heavy metal ion concentrations were displayed as averaged values from two reads on the ICP-MS.

\section{Results}

\subsection{Metagenomics Analysis Revealed Enrichment of Acinetobacter spp. Post Wastewater Treatment}

To determine the bacterial composition of the wastewater samples, samples collected in July 2015, October 2015 and November 2015 were pooled and their extracted nucleic acids were sequenced by omics-based sequencing. The sequencing reads were compared against a collated bacterial database. Figure 1 shows the detection of microorganisms throughout the WWTP at the genus and species levels. Further classification of microorganisms at the kingdom, phylum, class and family levels were listed in the Supplementary Materials (Figures S2-S5).

While viruses and archaea decreased in relative abundance down the treatment process, bacteria increased in relative abundance in the effluent and chlorinated effluent compared to the influent (Figure S2). A similar observation was seen at the phylum level with bacteria belonging to Proteobacteria compared to the other phyla (Figure S3). Out of the 22 classes of bacteria detected in this study, members of the Gammaproteobacteria and Actinobacteria increased in relative abundance in the effluent and continued to increase in the chlorinated effluent (Figure S4). Members of Gammaproteobacteria accounted for the highest relative abundance within the total microbial community in the chlorinated effluent. A further examination at the lower taxonomical levels revealed that the Moraxellaceae accounted for the highest relative abundance of the detected Gammaproteobacteria class (Figure S5). Specifically, the only genus detected in this WWTP belonging to the Moraxellaceae was Acinetobacter. Members of this genera were detected in increasing relative abundances in the effluent and the chlorinated effluent, similar to the trend observed at the family level.

Out of the 50 most detected species, five belonged to the Acinetobacter genus (Figure 1A). Two of these strains were detected at higher relative abundances in the chlorinated effluent than in the influent (A. venetians and A. junii). 
A.
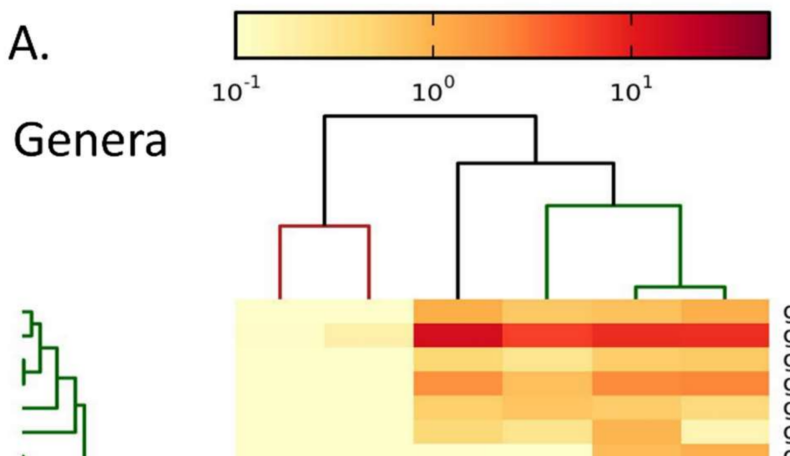

g_Sinobacteraceae_unclassified g-Sphingopyxis

g_Afipia

g-Blastomonas

- Bordetella

g-Cellvibrio

g_-Potyvirus

g_Methylibium

g-Thiobacillus

g_-Mycobacterium

g- Nocardioides

g-Acidovorax

g-Acinetobacter

g_- Caulobacter

g_Caulobacter

g_Cupriavidus

g-Brevundimonas

g_Fluviicola

g-Achromobacter

g_-Sphingobium

g-Variovorax

g-Delftia
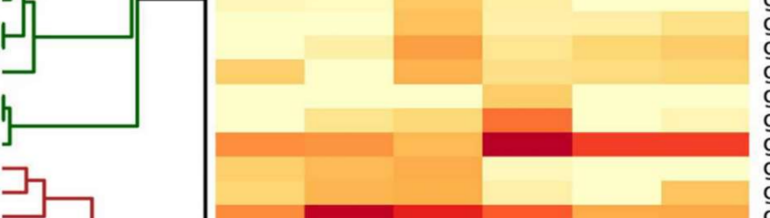

Methyloversatilis

g_Limnobacter

g_Thauera

g_Alicycliphilus

g_Siphoviridae noname

g_Aquaspirillum

g_Aeromonas

g_Azospira

g_Desulfovibrio

g-Laribacter

g_Comamonas

g_Yualikevirus

g_Bppunalikevirus

g_-Myroides

g_Polynucleobacter

g_-Pseudomonas

g_-Myoviridae noname

g-Prevotella

g-Eubacterium

g-Riemerella

g-Ruminococcus

- - Racteroides

g- Bacteroides

g_Faecalibacterium

IR IW ER EW CR CW

Figure 1. Cont. 


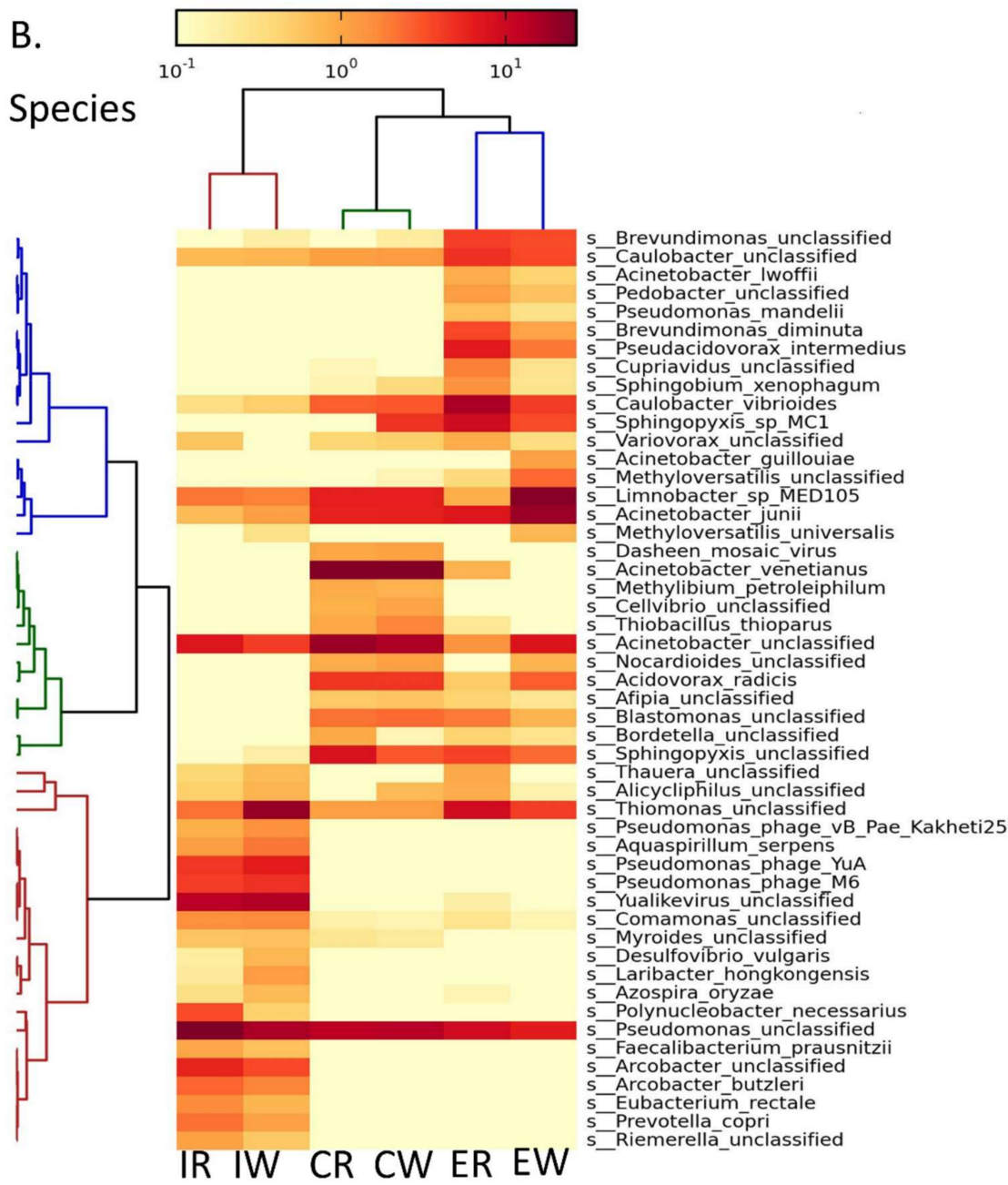

Figure 1. Heat map representing relative abundances of genera (A) and species (B), detected in the wastewater samples collected in July, October and November 2015. Colored scale bar represents the relative abundances for each heat map. IR: Influent-retentate, IW: Influent-wash, ER: Effluent-retentate, EW: Effluent-wash, CR: Chlorinated Effluent-retentate, CW: Chlorinated Effluent-wash.

\subsection{Gene Expression Analysis Revealed an Increase in Gene Expression of Acinetobacter junii Post MBR and} Chlorination

Acinetobacter junii has been shown to an opportunistic pathogen $[26,39]$ and since the chlorinated effluent is being introduced into the environment, further analysis of this species from the 2015 wastewater samples were carried out using metatranscriptomics approach.

A total of 288 genes ( $8.9 \%$ of genome) were found to be significantly upregulated in the effluent. This number increased to $378(11.7 \%)$ in the chlorinated effluent. The effluent and chlorinated effluent shared 98 genes (3.1\%) which were upregulated (Figure S1A). Thirty-five of these 98 genes were not classified by RAST. The largest category of the upregulated genes belonged to the cellular repair $(n=25)$ and metabolism $(n=15)$ categories. The remaining genes were involved in resistance $(n=9)$, signaling $(n=7)$, virulence $(n=5)$, stress response $(n=4)$, regulation of transcription and translation $(n=3)$ (Table 1). All 288 and 378 genes that were upregulated in the effluent and the chlorinated effluent are listed in Tables S4 and S5.

A. junii displayed $13(0.4 \%)$ and $121(3.8 \%)$ downregulated genes in the effluent and chlorinated effluent. Only $6(0.19 \%)$ of these downregulated genes were shared between the effluent and chlorinated effluent (Figure S1B). Two of these 6 genes were involved in cellular repair with the rest not being categorized (Table 2). 
Table 1. Genes of Acinetobacter junii that were upregulated in both the effluent and chlorinated effluent. The gene expression values of the effluent-retentate and chlorinated effluent-retentate were compared to the gene expression values of the influent-retentate. The gene expression values of the effluent-wash and chlorinated effluent-wash were compared to the gene expression values of the influent-wash. Each of these upregulations were included if they were more than two-fold change and were statistically significant $(p<0.05)$ on the Baggerly proportion-based test. Genes without any known classifications were omitted. More intense red shading signified a high fold induction.

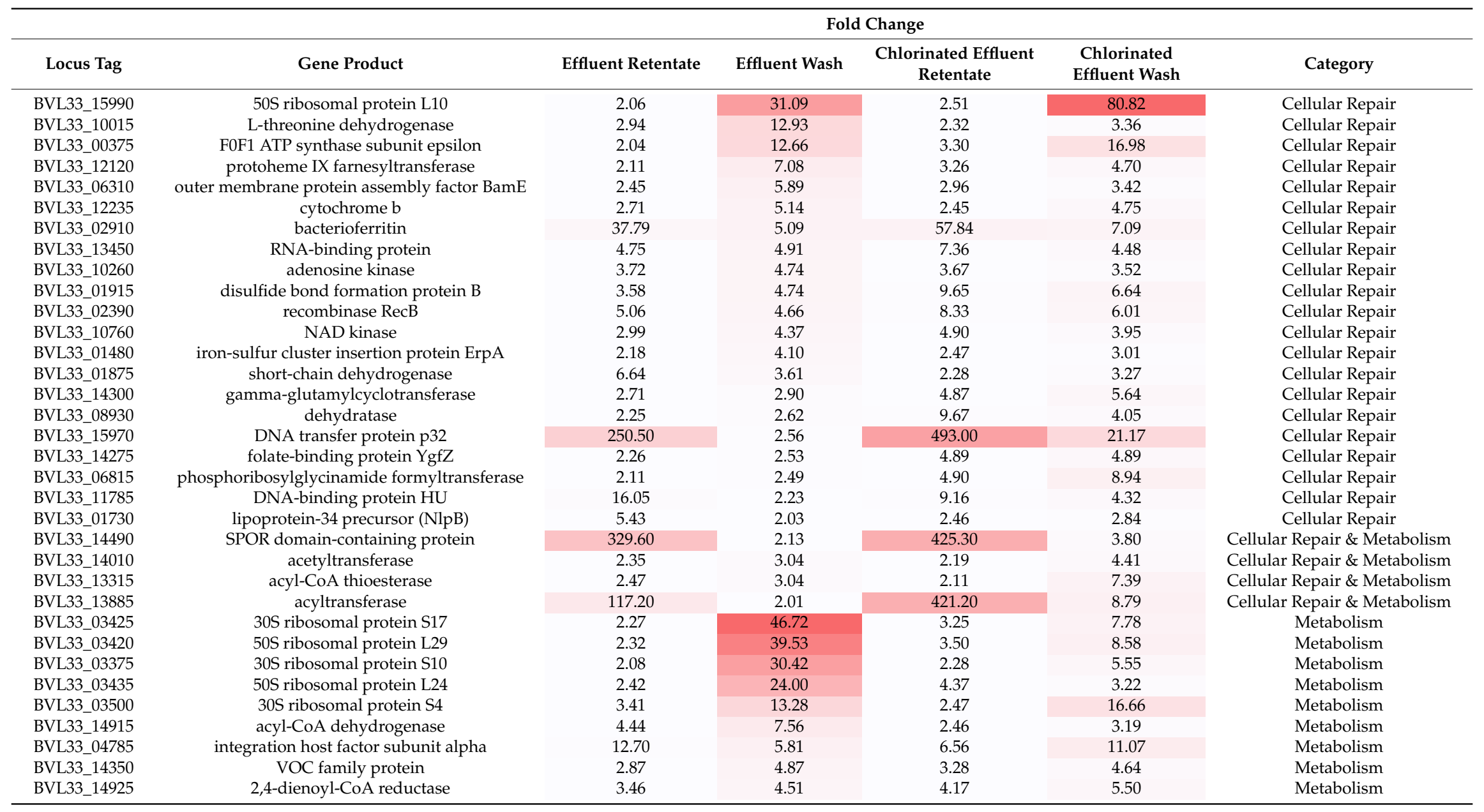


Table 1. Cont.

\begin{tabular}{|c|c|c|c|c|c|c|}
\hline \multirow[b]{2}{*}{ Locus Tag } & \multicolumn{6}{|c|}{ Fold Change } \\
\hline & Gene Product & Effluent Retentate & Effluent Wash & $\begin{array}{c}\text { Chlorinated Effluent } \\
\text { Retentate }\end{array}$ & $\begin{array}{l}\text { Chlorinated } \\
\text { Effluent Wash }\end{array}$ & Category \\
\hline BVL33_04625 & 3-hydroxyisobutyrate dehydrogenase & 3.14 & 3.10 & 2.44 & 3.25 & Metabolism \\
\hline BVL33_03235 & GTP cyclohydrolase II & 6.02 & 2.98 & 6.53 & 3.89 & Metabolism \\
\hline BVL33_13355 & SCP-2 sterol transfer family protein & 3.01 & 6.90 & 3.02 & 13.07 & Metabolite Transport \\
\hline BVL33_02100 & IS4 family transposase & 15.00 & 4.70 & 77.00 & 6.11 & Resistance \\
\hline BVL33_15710 & $\mathrm{Na}+/ \mathrm{H}+$ antiporter subunit $\mathrm{C}$ & 5.83 & 8.50 & 4.87 & 33.77 & Resistance \\
\hline BVL33_10090 & MBL fold metallo-hydrolase & 7.89 & 5.56 & 14.22 & 8.98 & Resistance \\
\hline BVL33_13770 & efflux transporter periplasmic adaptor subunit & 4.53 & 4.02 & 5.41 & 2.33 & Resistance \\
\hline BVL33_13780 & adenosine deaminase & 6.49 & 3.83 & 3.28 & 2.04 & Resistance \\
\hline BVL33_01605 & efflux transporter periplasmic adaptor subunit & 4.76 & 2.33 & 2.46 & 3.82 & Resistance \\
\hline BVL33 11410 & glutathione S-transferase & 3.46 & 2.77 & 3.26 & 2.52 & Resistance \& Signalling \\
\hline BVL33_11715 & glutathione S-transferase & 4.52 & 2.51 & 2.46 & 3.09 & Resistance \& Signalling \\
\hline BVL33_14240 & response regulator & 2.51 & 9.69 & 3.70 & 60.47 & Signalling \\
\hline BVL33_02040 & ion channel protein Tsx & 3.37 & 7.82 & 9.72 & 2.61 & Signalling \\
\hline BVL33_13200 & co-chaperone GroES & 2.70 & 6.16 & 2.82 & 4.36 & Signalling \\
\hline BVL33 14235 & response regulator & 5.73 & 3.49 & 4.93 & 2.63 & Signalling \\
\hline BVL33_14220 & hybrid sensor histidine kinase/response regulator & 4.35 & 2.94 & 2.00 & 2.01 & Signalling \\
\hline BVL33_04800 & thiol reductase thioredoxin & 4.42 & 9.02 & 4.23 & 4.60 & Stress Response \\
\hline BVL33_12425 & superoxide dismutase & 4.44 & 6.13 & 3.76 & 19.06 & Stress Response \\
\hline BVL33_13710 & transcriptional regulator & 63.30 & 4.46 & 226.20 & 7.05 & Transcriptional Regulator \\
\hline BVL33 07060 & serine protease & 3.54 & 2.27 & 2.11 & 3.06 & Transcriptional Regulator \\
\hline BVL33_04615 & ribosome silencing factor RsfS & 2.76 & 9.01 & 2.47 & 17.79 & Translation Regulator \\
\hline BVL33_14205 & entericidin, EcnA/B family & 5.45 & 11.83 & 2.47 & 12.14 & Virulence, Disease \& Defense \\
\hline BVL33_14745 & preprotein translocase subunit YajC & 14.79 & 8.03 & 4.87 & 10.43 & Virulence, Disease \& Defense \\
\hline BVL33_04950 & protein FilA & 17.07 & 5.88 & 4.21 & 9.87 & Virulence, Disease \& Defense \\
\hline BVL33_15450 & HopJ type III effector protein & 146.90 & 4.97 & 792.20 & 4.59 & Virulence, Disease \& Defense \\
\hline BVL33_09420 & $\begin{array}{l}\text { bifunctional adenosylcobinamide } \\
\text { kinase/adenosylcobinamide-phosphate } \\
\text { guanylyltransferase }\end{array}$ & 63.40 & 2.24 & 170.20 & 13.80 & Virulence, Disease \& Defense \\
\hline
\end{tabular}


Table 2. Genes of Acinetobacter junii that were downregulated in both the effluent and chlorinated effluent. The gene expression values of the effluent-retentate and chlorinated effluent-retentate were compared to the gene expression values of the influent-retentate. The gene expression values of the effluent-wash and chlorinated effluent-wash were compared to the gene expression values of the influent-wash. Each of these downregulations were included if they were less than -2-fold change and were statistically significant $(p<0.05)$ on the Baggerly proportion-based test. The magnitude of downregulation is indicated by the intensity of green shading.

\begin{tabular}{|c|c|c|c|c|c|c|}
\hline \multirow[b]{2}{*}{ Locus Tag } & \multirow[b]{2}{*}{ Gene Product } & \multicolumn{4}{|c|}{ Fold Change } & \multirow[b]{2}{*}{ Category } \\
\hline & & $\begin{array}{l}\text { Effluent } \\
\text { Retentate }\end{array}$ & Effluent Wash & $\begin{array}{c}\text { Chlorinated Effluent } \\
\text { Retentate }\end{array}$ & $\begin{array}{c}\text { Chlorinated Effluent } \\
\text { Wash }\end{array}$ & \\
\hline BVL33_10620 & thiamine biosynthesis protein ThiS & -2.16 & -30.91 & -90.70 & -139.10 & Cellular Repair \\
\hline BVL33_11020 & (4Fe-4S)-binding protein & -2.16 & -50.30 & -72.30 & -150.90 & Cellular Repair \\
\hline BVL33_15925 & hypothetical protein & -4.31 & -104.94 & -192.00 & -2.43 & None \\
\hline BVL33_00180 & hypothetical protein & -88.10 & -90.14 & -88.10 & -126.20 & None \\
\hline BVL33_03255 & hypothetical protein & -2.16 & -4.66 & -83.20 & -3.89 & None \\
\hline BVL33_06630 & amino acid transport protein & -88.10 & -6.40 & -88.10 & -6.40 & None \\
\hline
\end{tabular}




\subsection{Cellular Repair Genes Upregulated in Both Effluent and Chlorinated Effluent}

The largest category of genes upregulated in both effluents were involved in cellular repair (Table 1). Two of the most upregulated genes in this category are BVL33_14490 and BVL33_15970 which encode for a SPOR domain-containing protein and a DNA transfer protein, p32, respectively. These genes are highly upregulated in the retentate samples (329.6 and 250.5 times in the effluent retentate and 425.3 and 493 times in the chlorinated effluent, respectively). These genes were upregulated 2.13 and 2.56 times in the effluent wash and 3.8 and 21.17 times in the chlorinated effluent wash.

RecB recombinase, encoded by BVL33_02390, was upregulated 5.06 and 4.66 times in the effluent retentate and wash, respectively, and 8.33 and 6.01 times in the chlorinated effluent and wash, respectively. BVL33_06310 encodes for an outer membrane protein assembly factor. This gene was upregulated 2.45 and 5.89 times in the effluent retentate and wash, respectively, and 2.96 and 3.42 times in the chlorinated effluent retentate and wash, respectively.

Another gene of note in this category is BVL33_11785, encoding for a DNA binding protein. This gene was upregulated 16.05 and 2.23 times in the effluent retentate and wash, respectively, and 9.16 and 4.32 times in the chlorinated effluent retentate and wash, respectively (Table 1).

\subsection{Metabolism Genes Upregulated in Both Effluent and Chlorinated Effluent}

The second most abundant upregulated category in both effluents were genes involved in metabolism (Table 1). Five of the 11 genes upregulated were ribosomal proteins (BVL33_03425, BVL33_03420, BVL33_03375, BVL33_03435 and BVL33_3500). A sixth ribosomal protein was significantly upregulated in the cellular repair category. These genes were upregulated at an average of 30.84 and 20.44 in the effluent wash and chlorinated effluent wash, respectively. This was higher than the average upregulation of genes in either sample (6.40 and 9.08, respectively). These same genes were upregulated at an average of 2.43 and 3.06 times in the effluent retentate and the chlorinated effluent retentate, respectively (Table 1 ).

BVL33_13885, which belonged to both the cellular repair and metabolism categories, was upregulated 117.2 and 2.01 times in the effluent retentate and wash, respectively, and 421.2 and 8.79 times in the chlorinated effluent retentate and wash, respectively (Table 1). This gene encodes for an acyltransferase. BVL33_13315, an acyl-CoA thioesterase (upregulated 2.47 and 3.04 times in effluent retentate and wash, respectively, and 2.11 and 7.39 times in chlorinated effluent retentate and wash, respectively) and BVL33_14010 an acyltransferase (upregulated 2.35 and 3.04 times in the effluent retentate and wash, respectively, and 2.19 and 4.41 times in chlorinated effluent retentate and wash, respectively), were upregulated in the same category. These genes could be involved in the same pathway. BVL33_14915 was upregulated 4.44 and 7.56 times in the effluent retentate and wash, respectively, and 2.46 and 3.19 times in the chlorinated effluent retentate and wash, respectively. This gene encodes for an acyl-CoA dehydrogenase, sharing a substrate with BVL33_13885 and BVL33_13315 (Table 1).

After these genes, the next most upregulated gene in the metabolism category was BVL33_04785, encoding for one of the two subunits comprising an integration host factor (IHF) protein complex. This gene was upregulated 12.7 and 5.81 times in the effluent retentate and wash, respectively, and 6.56 and 11.07 times in the chlorinated effluent retentate and wash, respectively.

\subsection{Resistance Genes Upregulated in Both Effluent and Chlorinated Effluent}

In both effluents, four different efflux pumps were upregulated among genes responsible for resistance. One of these genes, BVL33_02685, a sodium:proton antiporter, was upregulated 27.5 and 2.57 times in the effluent retentate and wash, respectively, and 144.50 and 7.71 times in the chlorinated effluent retentate and wash, respectively (Table 1).

Another mode by which resistance could be attained is by the upregulation of BVL33_10090, a Metallo- $\beta$-Lactamase (MBL) fold protein. This protein was upregulated 7.89 and 5.56 times in the 
effluent retentate and wash, respectively, and 14.22 and 8.98 times in the chlorinated effluent retentate and wash, respectively (Table 1 ).

BVL33_02100, encoding for an IS4 transposase, was upregulated 15 and 4.7 times in the effluent retentate and wash, respectively, and 77 and 6.11 times in the chlorinated effluent retentate and wash, respectively (Table 1 ).

\subsection{Stress Response Genes Upregulated in Both Effluent and Chlorinated Effluent}

Out of the four genes upregulated in both effluents from the stress response category, BVL33_12940 was highly upregulated in the retentates. This gene was associated with DNA starvation and stationary phase protection, and was upregulated 832.9 and 3.5 times in the effluent retentate and wash, respectively. The gene was also upregulated 179.5 and 2.17 times in the chlorinated effluent retentate and wash, respectively. Another gene within this category was BVL33_00220, which encodes for an NADPH-dependent FMN reductase. This gene was upregulated 2.24 and 5.24 times in the effluent retentate and wash, and 19.19 and 27.53 times in the chlorinated effluent retentate and wash, respectively (Table 1 ).

\subsection{Virulence, Disease and Defense Genes Upregulated in Both Effluent and Chlorinated Effluent}

BVL33_15450, which encodes for a HopJ type III effector protein was upregulated 146.9 and 4.97 times in the effluent retentate and wash, respectively, and 792.2 and 4.59 times in the chlorinated effluent retentate and wash, respectively. Within this category, BVL33_04950 was upregulated 17.07 and 5.88 times in the effluent retentate and wash samples, respectively, and 4.21 and 9.87 times in the chlorinated effluent retentate and wash samples, respectively. This gene encodes for Protein FilA, which is a pili related gene (Table 1).

\subsection{Genes Upregulated Exclusively in the Effluent}

Table S4 lists all of the genes that were upregulated in the effluent. Three genes which are involved in the translocation of proteins across the cytoplasmic membrane were observed to be upregulated in the effluent. BVL33_15770 (SecG), BVL33_00120 (Sec-C), BVL33_03480 (SecY) and BVL33_04010 (SecB) were upregulated only in the effluent (Table S4).

The effluent displayed a total of 12 metal-related genes (MRGs): five metal dependent hydrolases (BVL33_03340, BVL33_06175, BVL33_06180, BVL33_10645 and BVL33_14520), a copper oxidase (BVL_05035), a copper translocating P-type ATPase (BVL33_06435), Cu(I)-responsive transcriptional regulator (BVL33_06430), two heavy metal transport/detox protein genes (BVL33_02645 and BVL33_06425), a metal binding protein (BVL33_13790) and a zinc metalloprotease (BVL33_13370) (Table S4). Two of these metal dependent hydrolases (BVL33_03340 and BVL33_06175) were also seen in the chlorinated effluent (Table 1). Furthermore, BVL33_02700, an efflux transporter periplasmic adaptor subunit that is involved in metal efflux and antibiotic resistance, was also upregulated in effluent but not in chlorinated effluent (Table S4).

The effluent also saw an increase in motility related genes other than BVL33_04950 (Protein FilA), which was seen in both effluents. BVL33_02830, a hypothetical type IV pilus protein and BVL33_02810, encoding for a pilus assembly protein PilM, was upregulated in the effluent retentate and wash exclusively (Table S4).

\subsection{Genes Upregulated Exclusively in the Chlorinated Effluent}

All of the upregulated genes of the chlorinated effluent are listed in Table S5. A different set of genes involved in the translocation of proteins across the cytoplasmic membrane was upregulated in the chlorinated effluent. These include BVL33_14755 (SecF), and BVL33_16010 (SecE) (Table S5).

In the chlorinated effluent samples, seven more MRGs were seen, which are not listed in Table 1: three copper resistance genes (BVL33_06020 and BVL33_06015, BVL_07275), three metal dependent 
hydrolases (BVL33_08355, BVL33_08360 and BVL33_08940) and a zinc dependent oxioreductase (BVL33_08650) (Table S5).

In addition to BVL33_13770 and BVL33_15710, which were upregulated in the resistance category (Table 1), BVL33_15705, encoding for a cation/proton antiporter, was upregulated exclusively in the chlorinated effluent (Table S5). Two other efflux transporter periplasmic adaptor subunit genes were upregulated in the chlorinated effluent but not the effluent (BVL33_06415 and BVL_11495) (Table S5).

Exclusively in the chlorinated effluent, four more genes were upregulated from the virulence category: two pili assembly proteins (BVL33_08765 and BVL33_02825 (PilP)), a PilZ domain-containing protein (BVL33_06780) and a hypothetical type IV pilus biogenesis protein (PilN) (BVL33_02815) (Table S5).

\subsection{Differential Upregulation of Genes in Retentate and Wash Samples}

Interestingly, genes were upregulated to different extents between the retentate and wash samples $(p<0.05)$. The color scale in Table 1 shows this distinct pattern with more intense red signifying a high fold induction. On average, each gene was upregulated 60.15 and 65.65 times in the effluent retentate and the chlorinated effluent retentate while genes were only upregulated 6.34 and 8.99 times in the effluent wash and chlorinated effluent wash, respectively. Genes which were highly upregulated in the effluent retentate were upregulated to similar extents in the chlorinated effluent retentate. To exemplify, genes BVL33_14490 and BVL33_15970 were highly upregulated in the effluent retentate (329.6 and 250.5 times, respectively) and the chlorinated effluent retentate (425.3 and 493 times, respectively). These genes were not as upregulated in the wash samples with 2.13- and 2.56-fold induction in the effluent wash and 3.80- and 21.17-fold induction in the chlorinated effluent wash. Conversely, BVL33_15990 and BVL33_03500 were highly upregulated in the effluent wash samples (31.09 and 13.28 times, respectively) and the chlorinated effluent wash (80.82 and 16.66 times, respectively) but were not upregulated as extensively in the retentates samples (Table 1). No similar trend was observed in the downregulated genes (Table 2).

\subsection{Validation of RNA-seq Data with RT-qPCR}

To validate the RNA-seq data, extracted RNA from the 2015 wastewater samples as well as the wastewater collected in October 2017 were analyzed by RT-qPCR. Messenger RNA (mRNA) levels belonging to gene categories; cellular repair (BVL33_01915, BVL33_02390 and BVL33_15970) (Figure 2), resistance (BVL33_13780 and BVL33_05485) (Figure 3), stress response (BVL33_12425 and BVL33_12940) (Figure 4) and virulence (BVL33_09420 and BVL33_02700) (Figure 5) were quantified and normalized against rpoB gene expression. All of the genes selected for this analysis were shown to be upregulated in both the effluent and chlorinated effluent in the RNA-seq analysis (Table 1).

RT-qPCR analysis showed a distinct upregulation in each of the genes analysed in the effluent and chlorinated effluent (Figures 2A, 3A, 4A and 5A). This finding concurs with the RNA-seq analysis and proves increased transcriptional activity in A. junii post MBR treatment. A similar trend was observed for wastewater collected in 2017, except for a slight decrease between influent-wash and effluent-wash for gene BVL33_02390 (Figure 2B), a significant downregulation in both the effluent and chlorinated effluent for BVL33_12425 (Figure 4B) and similar expression values between influent and effluent of BVL33_09420 (Figure 5B). Despite sampling two years apart, a similar general upregulation in genes correlating to cellular repair, resistance, virulence and stress response was seen, indicating that $A$. junii is active post MBR treatment over a certain temporal interval. 
A. Jul-Nov 2015 Wastewater

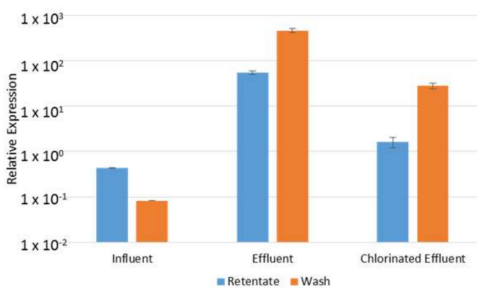

B. Oct 2017 Wastewater

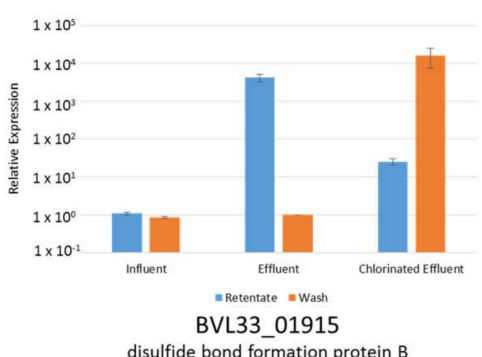

Cellular Repair
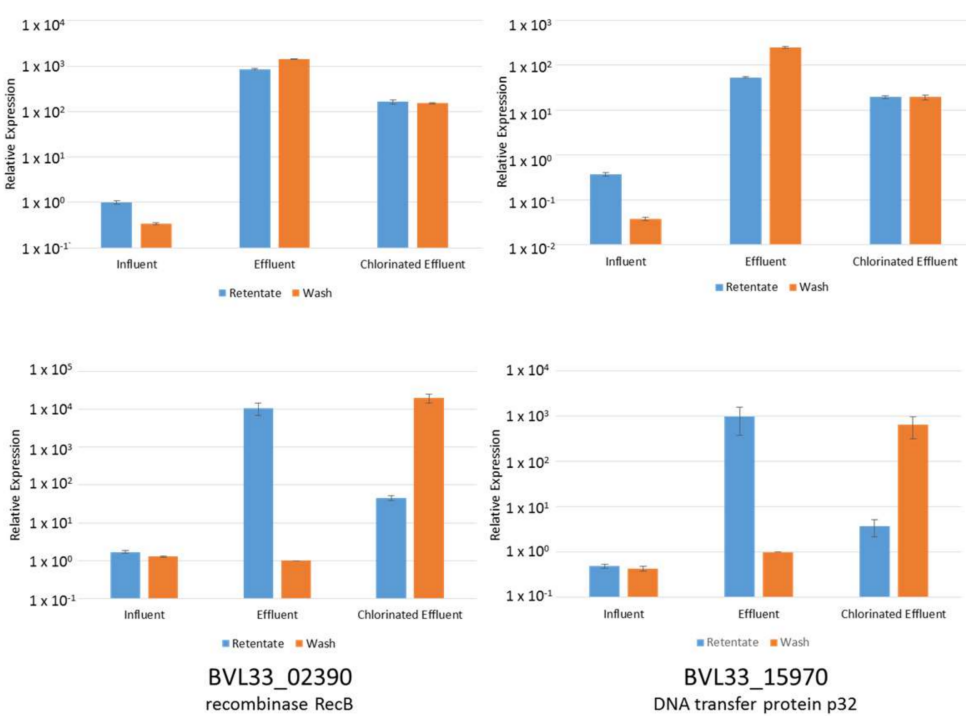

Figure 2. Relative expression profiles of $A$. junii genes involved in cellular repair. These genes displayed >2-fold change on RNA-seq analysis of wastewater sampled in July-November 2015 (Table 1). Gene expression values were normalized against a housekeeping rpoB gene. (A) Wastewater sampled in July, October and November of 2015; and (B) wastewater sampled in October 2017

\section{A. Jul-Nov 2015 Wastewater}

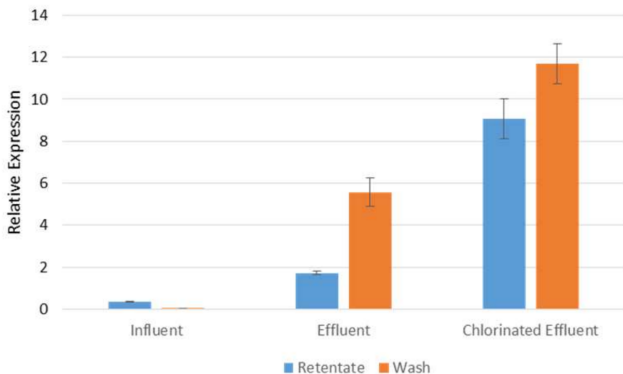

\section{B. Oct 2017 Wastewater}

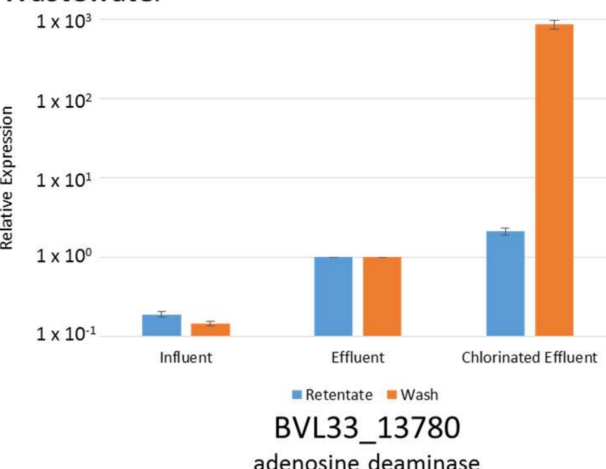

\section{Resistance}
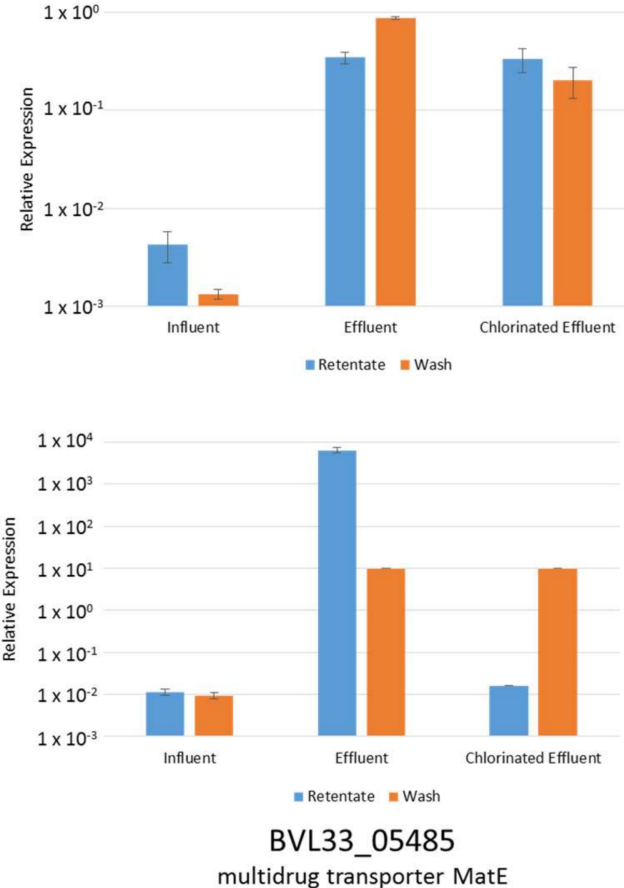

Figure 3. Relative expression profiles of $A$. junii genes involved in resistance. These genes displayed >2-fold change on RNA-seq analysis of wastewater sampled in July-November 2015 (Table 1). Gene expression values were normalized against a housekeeping rpoB gene. (A) Wastewater sampled in July, October and November of 2015; and (B) wastewater sampled in October 2017. 
A. Jul-Nov 2015 Wastewater

Stress Response
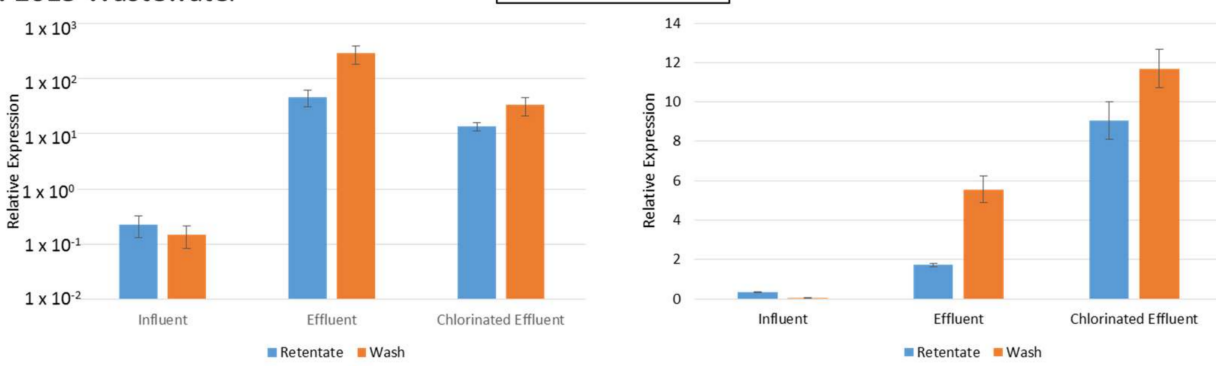

B. Oct 2017 Wastewater

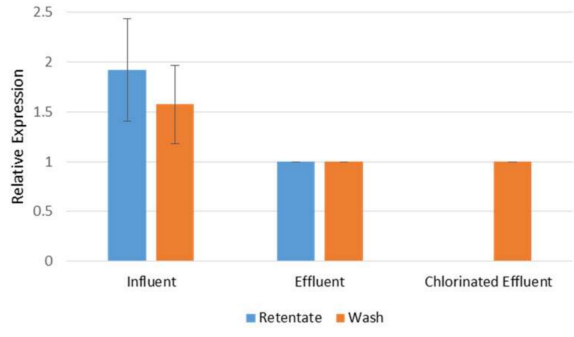

BVL33_12425

superoxide dismutase

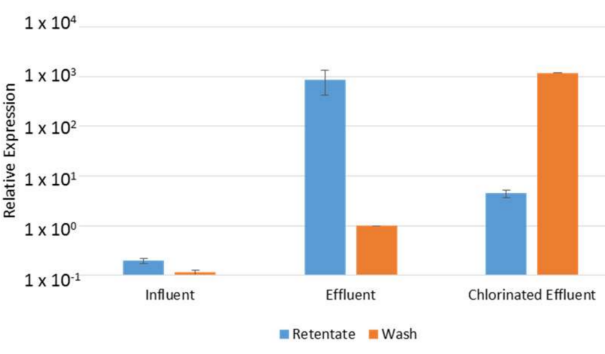

BVL33_12940

DNA starvation/stationary phase protection

Figure 4. Relative expression profiles of A. junii genes involved in stress response. These genes displayed $>2$-fold change on RNA-seq analysis of wastewater sampled in July-November 2015 (Table 1). Gene expression values were normalized against a housekeeping rpoB gene. (A) Wastewater sampled in July, October and November of 2015; and (B) wastewater sampled in October 2017.

A. Jul-Nov 2015 Wastewater

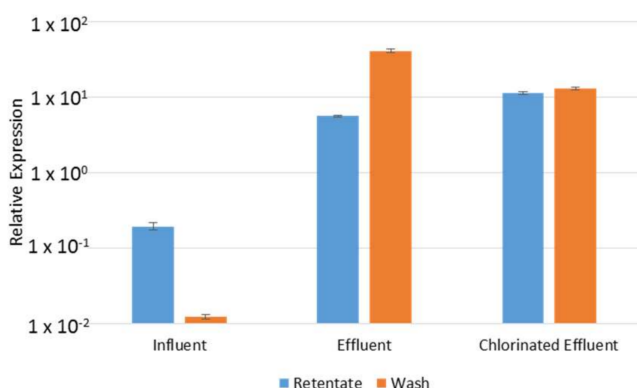

\section{B. Oct 2017 Wastewater}

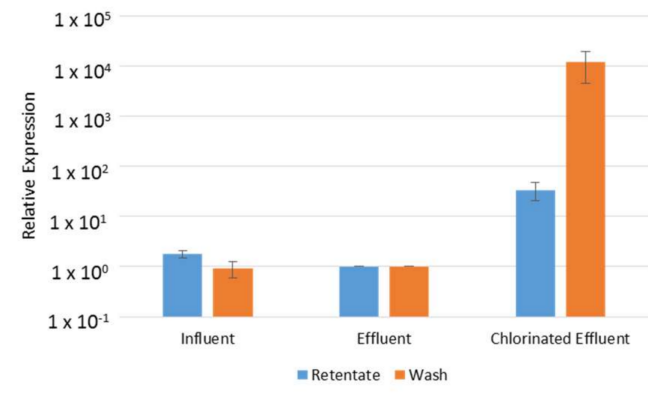

BVL33 09420

bifunctional adenosylcobinamide

\section{Virulence}

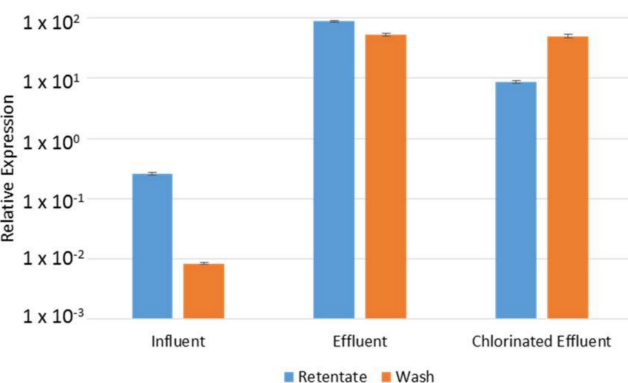

$1 \times 10^{4}$

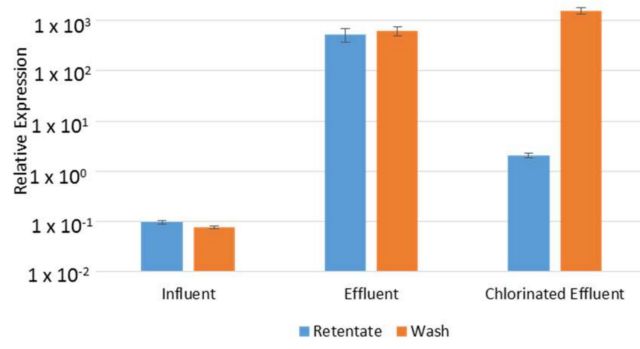

BVL33 02700

Efflux transporter periplasmic adaptor subunit

Figure 5. Relative expression profiles of $A$. junii genes involved in virulence. These genes displayed $>2$-fold change on RNA-seq analysis of wastewater sampled in July-November 2015 (Table 1). Gene expression values were normalized against a housekeeping rpoB gene. (A) Wastewater sampled in July, October and November of 2015; and (B) wastewater sampled in October 2017. 


\subsection{Metal ion Concentrations in March 2016 and October 2017 Wastewater Samples}

Given that metal-related genes were upregulated post treatment, ICP-MS analysis was done on the wastewater samples from October 2017 to corroborate this observation. Table S6 lists the average values of each metal ion assayed. Majority of the detected metals decrease post treatment. To exemplify, ${ }^{24} \mathrm{Al},{ }^{55} \mathrm{Mn}$, and ${ }^{56} \mathrm{Fe}$ concentrations decreased significantly in both the effluent (0.43-, 0.26-, and 0.34-fold change, respectively) and the chlorinated effluent (0.69-, 0.35-, and 0.41-fold change, respectively). In contrast, several metals increased in concentrations post treatment. ${ }^{47} \mathrm{Ti}$ showed significant increases in both the effluent (2.33-fold change) and the chlorinated effluent (2.55-fold change). ${ }^{60} \mathrm{Ni}$ showed a significant increase in the effluent (1.4-fold increase) with a slight increase in the chlorinated effluent (1.2-fold increase). ${ }^{24} \mathrm{Mg}$ showed a 1.82-fold increase in the chlorinated effluent but no significant change in the effluent. The concentration of ${ }^{66} \mathrm{Zn}$ showed a huge increase in the chlorinated effluent (4.91-fold increase) compared to influent (Figure 6 and Table S6).

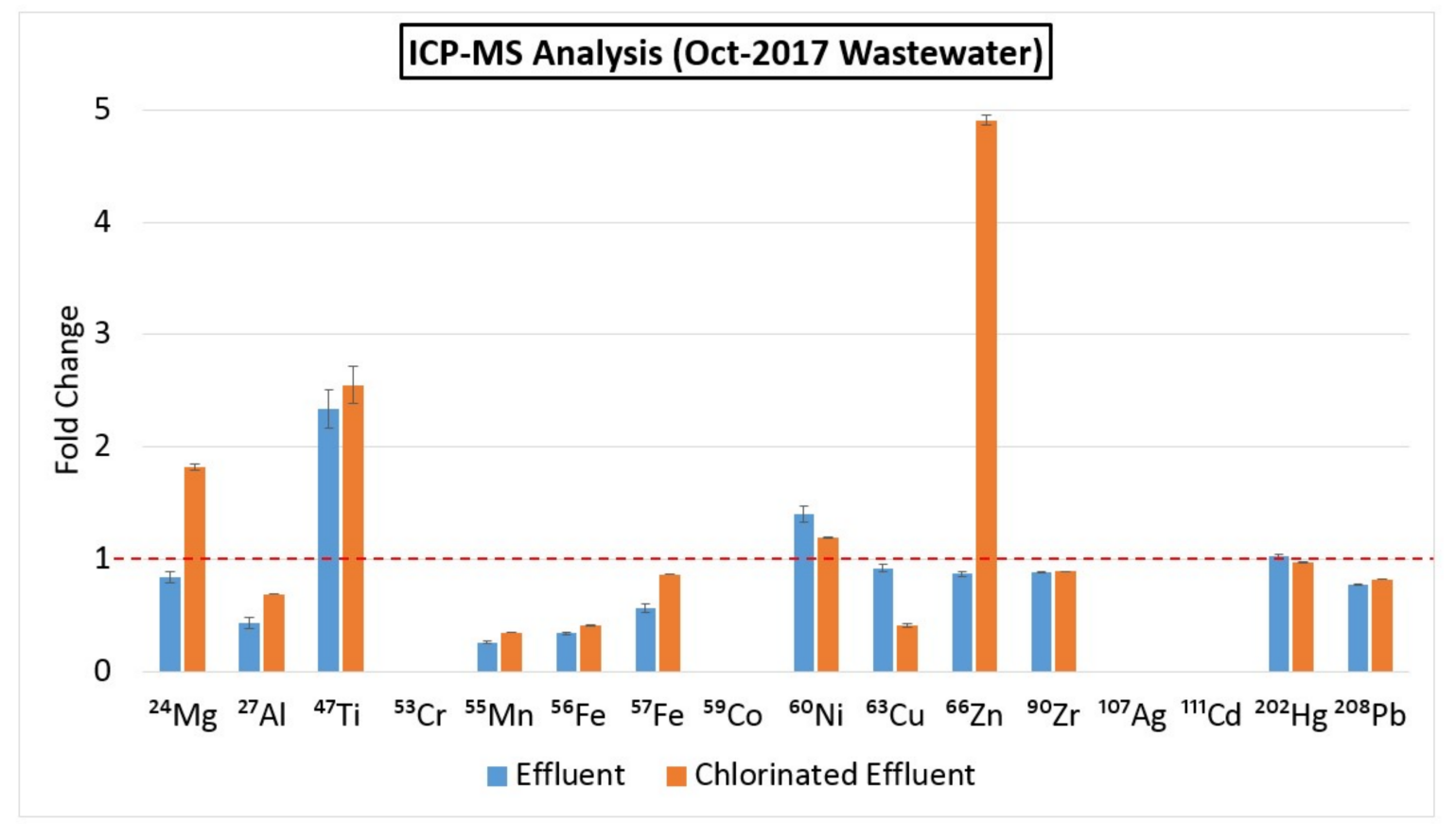

Figure 6. Fold Change of Metal Concentration in the effluent and chlorinated effluent in October 2017. Fold changes are measured with respect to the concentration in the influent. A fold change value of 1.0 implies no change (red dashed line). The numbers in superscript denote the atomic mass of the metal. Raw values of each ion as measured by ICP-MS are listed in Table S6.

\section{Discussion}

The WWTP in this study achieves microbial removal and inactivation by three different mechanisms. Firstly, nutrient removal is carried out by the activated sludge (reviewed in [40]). Secondly, microfiltration membranes submerged in the bioreactor separates microbes on basis of their size by filtration. Lastly, chlorination serves as a disinfection step which inactivates microbes in the effluent prior to discharge or reuse.

Despite the intended role of wastewater treatment process to remove and inactivate microorganisms, Acinetobacter spp. was detected in increasing abundances post MBR and chlorination (Figure 1). Four species of Acinetobacter (A. lwoffi, A. guillouiae, A. junii and A. venetanus) as well as unclassified species of Acinetobacter were detected following a similar trend, suggesting that all members of the Acinetobacter genus are constantly enriched compared to other bacterial populations in WWTPs. The enrichment of Acinetobacter spp. was also observed in another WWTP and at a different sampling period in 2012-2013 [4]. These findings suggest that Acinetobacter spp., particularly A. junii, 
have developed strategies to survive through the wastewater treatment train. Furthermore, since the metatranscriptomics data revealed an increase in Acinetobacter spp. activity down the WWTP, this suggests that members of the genus are both transcriptionally active and viable.

Metatranscriptomics was performed to elucidate the mechanisms adopted by A. junii to survive the treatment train. RNA-seq analysis was determined by comparing the mRNA expression values in the effluent and chlorinated effluent to the mRNA expression value of the influent. A main limitation of TFF is that the filtration membrane can foul rapidly if big particulates are not removed prior to filtration. Hence, particulates were first removed by centrifugation. Data pertaining to the influent in this study come from the supernatant fraction post centrifugation. Intact bacterial cells could be pelleted and removed, with only the supernatant fraction subjected to TFF. Therefore, the microbial load of the influent presented in this study might be an underrepresentation. However, majority of the bacterial species decreased in relative abundance in the effluent and chlorinated effluent (Figure 1 and Figures S2-S5), suggesting that the clarified influent still contains a relatively higher bacterial load despite the centrifugation step. Furthermore, gene expression comparisons are expressed as fold-expression values in this study, and are not affected by the microbial load of $A$. junii present at each stage of the WWTP.

Based on differential gene expression profiles, it is likely that $A$. junii upregulate genes related to metabolism and stress response to withstand the depleting nutrient in the sludge chambers, as well as upregulate genes related to cellular repair and resistance to counter the effects of chlorination.

To illustrate, among these gene categories, majority of the upregulated genes were related to cellular repair $(n=26)$ (Table 1$)$. In this category, BVL33_02390, encoding for recombinase recB was significantly upregulated. recB contains a helicase and single stranded DNA dependent-ATPase, and a domain which recruits other proteins involved in the DNA repair process [41]. This protein functions with recC and recD to form recBCD, and subsequently initiates repair of double stranded breaks in DNA [42]. The recBCD complex is present in most bacterial species including Acinetobacter spp. [43], and was also shown to be crucial in accepting DNA in transformation processes in A. baylyi [43]. In response to the damages incurred during the wastewater treatment process, recBCD might be required to remedy the double stranded breaks in the DNA by recombination or through foreign DNA acquired through transformation. However, recB was the only component of this complex which was upregulated in either the effluent or the chlorinated effluent (Table 1, Tables S4 and S5). This might suggest a role for recB in $A$. junii independent of recC and recD, which might not be determined as yet. An alternative repair mechanism may be initiated to provide redundancy in cell repair. Of note is gene BVL33_11785, encoding for a DNA-binding protein, HU. HU proteins are expressed in all bacterial species and function in DNA compaction, similar to histones in eukaryotes. These binding proteins form a stable protein-chromosome, preventing accumulation of mutations [44]. This compaction has been shown to protect the genome in response to reactive oxygen species, iron and copper toxicity, thermal stress, extreme $\mathrm{pH}$ and irradiation $[45,46]$. In E. coli, HU proteins are involved in repair of UV-damaged DNA by a recB-dependent pathway [47]. Understanding that recB was also upregulated, it is possible that this same pathway along with the HU protein, are being utilized to repair damaged DNA.

Furthermore, BamE, an outer membrane protein assembly factor, was upregulated in the cellular repair category. This protein is involved in the assembly and insertion of $\beta$-barrel proteins into the outer membrane together with four other proteins, BamA, BamB, BamC, and BamD, to produce the $\beta$-barrel-assembly machinery (BAM) complex [48]. By itself, BamE has been shown to bind to phosphotidylglycerol, possibly anchoring the BAM complex to the membrane [49]. Interestingly, E. coli lacking the bamE gene were found to be susceptible to vancomycin, creating the suggestion that an increasing BamE would make A. junii resistant to antibiotics [50]. However, this link has yet to be confirmed.

This protein complex functions after outer membrane proteins (OMPs) are synthesized in the cell and transported across the cytoplasmic membrane by the Sec translocon [51]. Even though 
the genes encoding for the rest of the BamABCDE complex were not observed to be upregulated, individual genes encoding for the Sec translocon were. The effluent saw an upregulation of $\sec G$, $\sec -\mathrm{C}$, and $\sec Y$ while the chlorinated effluent saw increases in secF and secE (Tables S4 and S5). The main translocon channel is composed of proteins SecY, SecE and SecG [52]. While secY, secE and $\sec G$ were not upregulated in both effluents, $\sec G$ and $\sec Y$ gene were upregulated in the effluent and by the time $A$. junii transitions to the chlorination chamber, these proteins would already be in abundance. The subsequent upregulation of secE in the chlorinated effluent would complete the SecYEG channel allowing for successful translocation. SecB, also upregulated in the effluent, serves as a chaperon protein, targeting OMPs to the SecYEG channel [53]. These upregulations indicate A. junii are actively facilitating OMP translocation and insertion into the outer membrane, possibly to replace damaged proteins incurred in WWTP. However, the lack of upregulation of the other components of the BAM complex might suggest that the upregulated BamE binds to endogenous BamA, BamB, BamC, and BamD or the mechanism of its action in this described scenario is not as expected.

Besides repairing and protecting the cell wall structure, it was observed that $A$. junii also actively upregulated genes, for example BVL33_13885, that was associated with both the cellular repair and metabolism pathways. This gene encodes for an acyltransferase protein, which has a primary function of transporting fatty acids for $\beta$-oxidation [54]. This is the first step in the pathway which oxidizes fatty acids in place of glucose as a carbon source. Acinetobacter spp. have been shown to resort to synthesizing wax esters and triacylglycerols under growth limiting conditions $[55,56]$. These compounds serve as an alternative energy source as well as protecting the cell from desiccation, irradiation and pathogens [57]. The upregulation of other genes involved in fatty acid metabolism (BVL33_13315, BVL33_14915 and BVL33_14010) in both effluents seem to indicate the increase in reliance on alternative carbon sources (Table 1). Furthermore, within the stress response category, BVL33_00220, encoding for an NADPH-dependent FMN reductase was upregulated. This protein has also been shown previously to allow A. baumannii to utilize $p$-hydroxyphenylacetate as an alternative carbon source [58]. If this function is similar, it might serve useful for $A$. junii in conditions of nutrient instability such as in a WWTP. Collectively, the upregulation of the genes suggest that there exists a strong selection pressure for $A$. junii to depend on alternative carbon sources for energy in a WWTP. This would provide Acinetobacter spp., an additional advantage to survive the fluctuating nutrient conditions of a WWTP and outcompete other strains in a WWTP.

In addition to active cell repair and expanding its carbon sources for metabolic needs, metatranscriptomics suggest that $A$. junii also upregulate resistance genes and stress response genes to facilitate survival. To exemplify, two of the genes upregulated in both effluents (BVL33_02685 and BVL33_01605) were efflux pumps for nickel, cadmium, cobalt and zinc (Table 1). Upregulation of these genes did not seem to correlate with the heavy metal concentrations since majority of the heavy metal concentrations decreased after treatment (Figure 6 and Table S6). However, earlier studies have reported a lack of correlation between the concentration of heavy metals and related resistance genes, suggesting that acute exposure of sub-lethal concentrations of these compounds were sufficient to trigger the expression of resistance genes [59,60]. Alternatively, the upregulation of these efflux pumps may be co-selected for by chlorination so as to regulate the concentration gradient of ROS generated in the chlorination chamber [61,62] and intracellularly [17]. Efflux pumps, conferring resistance to antibiotics, were upregulated in A. baumannii upon chlorination. Studies have linked the upregulation of efflux pumps in bacteria to damage and mutations incurred on the genome due to the action of chlorine-induced ROS [63,64]. In this study, BVL33_02685, had a higher fold change in the chlorinated effluent than the effluent, suggesting that chlorination might impose the selective pressure for this upregulation (Table 1).

Alternatively, BVL33_00220 which encodes for a DNA starvation/stationary phase protection protein was also highly upregulated. A similar protein in A. baylyi was shown to bind to DNA during stationary phase, forming a condensed and stable structure. This protein also protects the genome from oxidative stress by sequestering intracellular ions. The combined effects might serve to protect 
A. junii (considering common functionality) from the relative increase in metals seen in the chlorinated effluent (Figure 6 and Table S6) by entering into dormancy if the earlier approaches of active cell repair, expansion of metabolic substrates, and biofilm formation are insufficient to assist in its survival through the WWTP.

Furthermore, it was observed that the profiles of upregulated genes between the retentate and the wash samples differ significantly $(p<0.05)$ (Table 1$)$. In an earlier study of $A$. baumannii, the RNA expression profiles was observed to differ between planktonic and biofilm associated populations [65]. It is plausible that the RNA expression profiles of the retentate and wash of $A$. junii mirror that seen in planktonic and biofilm-associated A. baumannii. Strains which were isolated in the wash might be hydrophobic and hence adhere to the TFF membrane stronger, as compared to strains collected in the retentate. Hydrophilic strains would remain in suspension in the WWTP and escape sedimentation. The presence of different subpopulations of the same bacteria in a single environment has been shown to facilitate persistence. In conditions of harsh or changing environments, having different phenotypes may confer the microbe the ability to persist and achieve dominance [66,67]. The lesser transcriptionally active population of $A$. junii, found in the wash samples, may be entering a state of quiescence or dormancy and will regain activity when conditions change. Bacteria entering or exiting a state of quiescence have been shown to have an increase in protein production to facilitate de novo synthesis of metabolites in extreme conditions [68,69]. This could account for significant upregulation of ribosomal proteins in the wash samples (Table 1). This upregulation in transcriptional machinery may prime the cell for the further increase in protein synthesis [70]. The five most upregulated genes in the retentate, which were not as upregulated in the wash, were a DNA transfer protein, a SPOR-domain containing protein, an acyltransferase, a DNA starvation/stationary phase protection protein and a HopJ type III protein. These genes indicate that cells in the retentate are focused on DNA preservation, cell division and fatty acid metabolism. Retentate $A$. junii seems to be replicating rapidly and at the same time protecting its genome, which would be more susceptible to mutations and strand breaks during replication. The energy required for replication may come from the $\beta$-oxidation of fatty acids.

Collectively, this study provides data to suggest that $A$. junii adopted a multi-faceted approach, ranging from utilizing alternative carbon sources, preservation of its genome integrity, repairing OMPs, promoting growth of two different subpopulations and by actively extruding metals or reactive oxygen species to survive the wastewater treatment process (Figure 7).

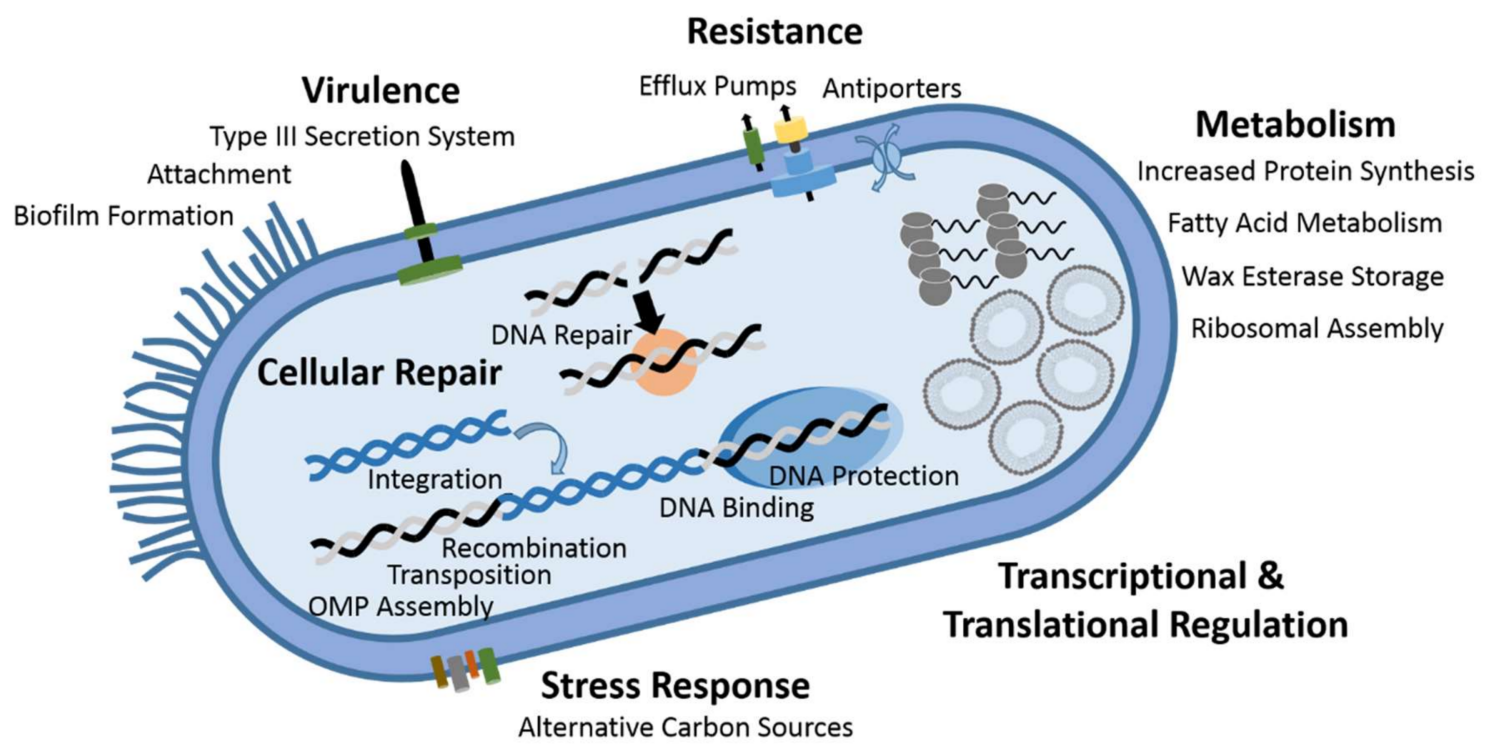

Figure 7. Classifications of upregulated genes in Acinetobacter junii in response to wastewater treatment. 
Given that A. junii is able to persist well in WWTP, perhaps concerning is the observation that BVL33_02100, encoding for an IS4 transposase was significantly upregulated in the retentate. The gene encoding for this insertion factor is ubiquitous throughout all domains of life but found to be actively transposing in only a few species [71]. Three active insertion factors, ISAba1, ISAba11 and A473, have been found in A. baumanii [72-74]. These genes have been shown to confer resistance to A. baumannii by disrupting genes which facilitate uptake of antibiotics [75] or by being powerful promoters to native resistance genes [76]. The function of this transposase may be enhanced by the upregulation of BVL33_15970, a DNA transfer protein. Both these proteins may function synergistically in lateral gene transfer, allowing for tolerance of the WWTP conditions and for A. junii to gain other gene functions.

In addition, the most upregulated gene in the "Virulence, Disease and Defense" category was BVL33_15450, encoding for a HopJ type III effector protein (Table 1). This protein has not been reported in Acinetobacter spp., but has been shown to be play a role in plant pathogenicity in Pseudomonas spp. [77]. While no evidence in this study links Acinetobacter spp. to plant pathogenicity directly, numerous studies have isolated Acintobacter spp., from vegetables globally, suggesting a possible relationship (reviewed in [78-81]). While the data show significant increases of $A$. junii gene expression down the WWT process, this study does not provide the actual cell density which would allow for proper assessment of risk. However, from the low number of Acintetobacter spp. isolated from the effluents of WWTP in Jeddah (Tables S1 and S2), it is likely that that viable A. junii would impose low risk. Therefore, although this study provides insights to understanding how $A$. junii persist throughout the WWTP, their persistence warrants no need for a massive revamp of existing WWTP. This is particularly the case for MBR-based WWTP, where a total eradication of Acinetobacter spp. would be impractical and costly.

Supplementary Materials: The following are available online at http:/ /www.mdpi.com/2073-4441/10/4/436/s1, Table S1: Antibiotic profile of species detected in the effluent wastewater from Al-Jassim et al., 2015 [4]. Grey circles indicate susceptibility. Values $>0.5$ (highlighted in red) indicate resistance. Amp: Ampicillin, Kan: Kanamycin, Erm: Erythromycin, Tet: Tetracycline, Cef: Cefuroxime, Chl: Chloramphenicol, Mer: Meropenem, Cip: Ciprofloxacin. Table S2: Antibiotic profile of species detected in the chlorinated effluent wastewater from Al-Jassim et al., 2015 [4]. Grey circles indicate susceptibility. Values $>0.5$ (highlighted inet: Tetracycline, Cef: Cefuroxime, red) indicate resistance. Amp: Ampicillin, Kan: Kanamycin, Erm: Erythromycin, TChl: Chloramphenicol, Mer: Meropenem, Cip: Ciprofloxacin. Table S3: Gene names, categories and primer sequences of genes assayed by RT-qPCR. Table S4: All 288 genes of Acinetobacter junii that were upregulated in the effluent. The gene expression values of the effluent-retentate and effluent-wash were compared to the gene expression values of the influent-retentate and influent-wash, respectively. All upregulations were included if they were more than two-fold change and were statistically significant $(p<0.05)$ on the Baggerly proportion-based test. Table S5: All 378 genes of Acinetobacter junii that were upregulated in the chlorinated effluent. The gene expression values of the chlorinated effluent-retentate and chlorinated effluent-wash were compared to the gene expression values of the influent-retentate and influent-wash, respectively. All upregulations were included if they were more than two-fold change and were statistically significant $(p<0.05)$ on the Baggerly proportion-based test. Table S6: ICP-MS analysis of the influent, effluent and chlorinated effluent of October 2017 Wastewater. Numbers in superscript refer to the atomic weight of the cation. Figure S1: Venn diagrams representing the numbers of significantly upregulated (A) and downregulated (B) genes only in the effluent (orange), chlorinated effluent (yellow) and in both effluent and chlorinated effluent (purple). Only genes that displayed a two-time up/downregulation and have $p<0.05$ on the Baggerly proportion-based test were considered as significant. Figure S2: Heat map representing relative abundances of the different kingdoms detected in the wastewater samples collected in July, October and November 2015. Colored scale bar represents the relative abundances for each heat map. IR: Influent-retentate, IW: Influent-wash, ER: Effluent-retentate, EW: Effluent-wash, CR: Chlorinated Effluent-retentate, CW: Chlorinated Effluent-wash. Figure S3: Heat map representing relative abundances of the different phyla detected in the wastewater samples collected in July, October and November 2015. Colored scale bar represents the relative abundances for each heat map. IR: Influent-retentate, IW: Influent-wash, ER: Effluent-retentate, EW: Effluent-wash, CR: Chlorinated Effluent-retentate, CW: Chlorinated Effluent-wash. Figure S4: Heat map representing relative abundances of the different classes detected in the wastewater samples collected in July, October and November 2015. Colored scale bar represents the relative abundances for each heat map. IR: Influent-retentate, IW: Influent-wash, ER: Effluent-retentate, EW: Effluent-wash, CR: Chlorinated Effluent-retentate, CW: Chlorinated Effluent-wash. Figure S5: Heat map representing relative abundances of the different families detected in the wastewater samples collected in July, October and November 2015. Colored scale bar represents the relative abundances for each heat map. IR: Influent-retentate, IW: Influent-wash, ER: Effluent-retentate, EW: Effluent-wash, CR: Chlorinated Effluent-retentate, CW: Chlorinated Effluent-wash. 
Acknowledgments: The authors would like to thank George Princeton Dunsford for access to the KAUST wastewater treatment plant and Moustapha Harb for providing sampling assistance. The research reported in this publication was supported by the KAUST baseline funding BAS/1/1033-01-01 awarded to Pei-Ying Hong.

Author Contributions: P.Y.-H. and M.R.J. conceived and wrote the manuscript. M.R.J., N.A.-J., H.C. and M.F.H. carried out the experiments. M.F.H. assisted in writing the manuscript.

Conflicts of Interest: The authors declare that the research was conducted in the absence of any commercial or financial relationships that could be construed as a potential conflict of interest.

\section{References}

1. Shomar, B. Water Resources, Water Quality and Human Health in Regions of Extreme Stress: Middle East. J. Earth Sci. Clim. Chang. 2013, 4, 1-12. [CrossRef]

2. Al-Jasser, A.O. Saudi wastewater reuse standards for agricultural irrigation: Riyadh treatment plants effluent compliance. J. King Saud Univ. Eng. Sci. 2011, 23, 1-8. [CrossRef]

3. Webb, A.L.; Taboada, E.N.; Selinger, L.B.; Boras, V.F.; Inglis, G.D. Efficacy of wastewater treatment on Arcobacter butzleri density and strain diversity. Water Res. 2016, 105, 291-296. [CrossRef] [PubMed]

4. Al-Jassim, N.; Ansari, M.I.; Harb, M.; Hong, P.-Y. Removal of bacterial contaminants and antibiotic resistance genes by conventional wastewater treatment processes in Saudi Arabia: Is the treated wastewater safe to reuse for agricultural irrigation? Water Res. 2015, 73, 277-290. [CrossRef] [PubMed]

5. Sui, Q.; Jiang, C.; Yu, D.; Chen, M.; Zhang, J.; Wang, Y.; Wei, Y. Performance of a sequencing-batch membrane bioreactor (SMBR) with an automatic control strategy treating high-strength swine wastewater. J. Hazard. Mater. 2018, 342, 210-219. [CrossRef] [PubMed]

6. Wu, D.; Dolfing, J.; Xie, B. Bacterial perspectives on the dissemination of antibiotic resistance genes in domestic wastewater bio-treatment systems: Beneficiary to victim. Appl. Microbiol. Biotechnol. 2018, 102, 597-604. [CrossRef] [PubMed]

7. Lekunberri, I.; Balcazar, J.L.; Borrego, C.M. Metagenomic exploration reveals a marked change in the river resistome and mobilome after treated wastewater discharges. Environ. Pollut. 2017, 234, 538-542. [CrossRef] [PubMed]

8. Xiao, S.; Hu, S.; Zhang, Y.; Zhao, X.; Pan, W. Influence of sewage treatment plant effluent discharge into multipurpose river on its water quality: A quantitative health risk assessment of Cryptosporidium and Giardia. Environ. Pollut. 2017, 233, 797-805. [CrossRef] [PubMed]

9. Ajonina, C.; Buzie, C.; Rubiandini, R.H.; Otterpohl, R. Microbial pathogens in wastewater treatment plants (WWTP) in Hamburg. J. Toxicol. Environ. Health Part A 2015, 78, 381-387. [CrossRef] [PubMed]

10. Naidoo, S.; Olaniran, A.O. Treated wastewater effluent as a source of microbial pollution of surface water resources. Int. J. Environ. Res. Public Health 2014, 11, 249-270. [CrossRef] [PubMed]

11. Cai, L.; Zhang, T. Detecting human bacterial pathogens in wastewater treatment plants by a high-throughput shotgun sequencing technique. Environ. Sci. Technol. 2013, 47, 5433-5441. [CrossRef] [PubMed]

12. Judd, S. The status of membrane bioreactor technology. Trends Biotechnol. 2008, 26, 109-116. [CrossRef] [PubMed]

13. Iorhemen, O.T.; Hamza, R.A.; Tay, J.H. Membrane bioreactor (MBR) technology for wastewater treatment and reclamation: Membrane fouling. Membranes 2016, 6, 33. [CrossRef] [PubMed]

14. Pollice, A.; Laera, G.; Saturno, D.; Giordano, C.; Sandulli, R. Optimal sludge retention time for a bench scale MBR treating municipal sewage. Water Sci. Technol. 2008, 57, 319-322. [CrossRef] [PubMed]

15. Anastasi, E.M.; Wohlsen, T.D.; Stratton, H.M.; Katouli, M. Survival of Escherichia coli in two sewage treatment plants using UV irradiation and chlorination for disinfection. Water Res. 2013, 47, 6670-6679. [CrossRef] [PubMed]

16. Chapman, J.S. Disinfectant resistance mechanisms, cross-resistance, and co-resistance. Int. Biodeterior. Biodegrad. 2003, 51, 271-276. [CrossRef]

17. Zhang, Y.; Gu, A.Z.; He, M.; Li, D.; Chen, J. Subinhibitory concentrations of disinfectants promote the horizontal transfer of multidrug resistance genes within and across genera. Environ. Sci. Technol. 2017, 51, 570-580. [CrossRef] [PubMed]

18. Reactive Oxygen Species (ROS). 2015. Available online: http://www.biology-pages.info/R/ROS.html (accessed on 10 January 2018). 
19. Jumat, M.; Hasan, N.; Subramanian, P.; Heberling, C.; Colwell, R.; Hong, P.-Y. Membrane bioreactor-based wastewater treatment plant in Saudi Arabia: Reduction of viral diversity, load, and infectious capacity. Water 2017, 9, 534. [CrossRef]

20. Harb, M.; Hong, P.-Y. Molecular-based detection of potentially pathogenic bacteria in membrane bioreactor (MBR) systems treating municipal wastewater: A case study. Environ. Sci. Pollut. Res. 2017, 24, 5370-5380. [CrossRef] [PubMed]

21. Hrenovic, J.; Goic-Barisic, I.; Kazazic, S.; Kovacic, A.; Ganjto, M.; Tonkic, M. Carbapenem-resistant isolates of Acinetobacter baumannii in a municipal wastewater treatment plant, Croatia, 2014. Euro Surveill. 2016, 21. [CrossRef] [PubMed]

22. Zhang, Y.; Marrs, C.F.; Simon, C.; Xi, C. Wastewater treatment contributes to selective increase of antibiotic resistance among Acinetobacter spp. Sci. Total Environ. 2009, 407, 3702-3706. [CrossRef] [PubMed]

23. Oerther, D.B.; Pernthaler, J.; Schramm, A.; Amann, R.; Raskin, L. Monitoring Precursor 16S rRNAs of Acinetobacter spp. in Activated Sludge Wastewater Treatment Systems. Appl. Environ. Microbiol. 2000, 66, 2154-2165. [CrossRef] [PubMed]

24. Joly-Guillou, M.L. Clinical impact and pathogenicity of Acinetobacter. Clin. Microbiol. Infect. 2005, 11, 868-873. [CrossRef] [PubMed]

25. Linde, H.J.; Hahn, J.; Holler, E.; Reischl, U.; Lehn, N. Septicemia due to Acinetobacter junii. J. Clin. Microbiol. 2002, 40, 2696-2697. [CrossRef] [PubMed]

26. Hung, Y.T.; Lee, Y.T.; Huang, L.J.; Chen, T.L.; Yu, K.W.; Fung, C.P.; Cho, W.L.; Liu, C.Y. Clinical characteristics of patients with Acinetobacter junii infection. J. Microbiol. Immunol. Infect. 2009, 42, 47-53. [PubMed]

27. Cayo, R.; Yanez San Segundo, L.; Perez del Molino Bernal, I.C.; Garcia de la Fuente, C.; Bermudez Rodriguez, M.A.; Calvo, J.; Martinez-Martinez, L. Bloodstream infection caused by Acinetobacter junii in a patient with acute lymphoblastic leukaemia after allogenic haematopoietic cell transplantation. J. Med. Microbiol. 2011, 60 Pt 3, 375-377. [CrossRef] [PubMed]

28. Cooper, R.M.; Tsimring, L.; Hasty, J. Inter-species population dynamics enhance microbial horizontal gene transfer and spread of antibiotic resistance. eLife 2017, 6, E25950. [CrossRef] [PubMed]

29. Al Atrouni, A.; Joly-Guillou, M.-L.; Hamze, M.; Kempf, M. Reservoirs of non-baumannii Acinetobacter species. Front. Microbiol. 2016, 7, 49. [CrossRef] [PubMed]

30. Wiedmann-al-Ahmad, M.; Tichy, H.V.; Schön, G. Characterization of Acinetobacter type strains and isolates obtained from wastewater treatment plants by PCR fingerprinting. Appl. Environ. Microbiol. 1994, 60, 4066-4071. [PubMed]

31. Doughari, H.J.; Ndakidemi, P.A.; Human, I.S.; Benade, S. The ecology, biology and pathogenesis of Acinetobacter spp.: An overview. Microbes Environ. 2011, 26, 101-112. [CrossRef] [PubMed]

32. Montaña, S.; Cittadini, R.; del Castillo, M.; Uong, S.; Lazzaro, T.; Almuzara, M.; Barberis, C.; Vay, C.; Ramírez, M.S. Presence of New Delhi metallo- $\beta$-lactamase gene (NDM-1) in a clinical isolate of Acinetobacter junii in Argentina. New Microbes New Infect. 2016, 11, 43-44. [CrossRef] [PubMed]

33. Guardabassi, L.; Dalsgaard, A.; Olsen, J.E. Phenotypic characterization and antibiotic resistance of Acinetobacter spp. isolated from aquatic sources. J. Appl. Microbiol. 1999, 87, 659-667. [CrossRef] [PubMed]

34. Molina-Romero, D.; Baez, A.; Quintero-Hernández, V.; Castañeda-Lucio, M.; Fuentes-Ramírez, L.E.; Bustillos-Cristales, M.d.R.; Rodríguez-Andrade, O.; Morales-García, Y.E.; Munive, A.; Muñoz-Rojas, J. Compatible bacterial mixture, tolerant to desiccation, improves maize plant growth. PLoS ONE 2017, 12, E0187913. [CrossRef] [PubMed]

35. Bastian, R.; Murray, D. 2012 Guidelines for Water Reuse; EPA Office of Research and Development: Washington, DC, USA, 2012.

36. Bolger, A.M.; Lohse, M.; Usadel, B. Trimmomatic: A flexible trimmer for Illumina sequence data. Bioinformatics 2014, 30, 2114-2120. [CrossRef] [PubMed]

37. Truong, D.T.; Franzosa, E.A.; Tickle, T.L.; Scholz, M.; Weingart, G.; Pasolli, E.; Tett, A.; Huttenhower, C.; Segata, N. MetaPhlAn2 for enhanced metagenomic taxonomic profiling. Nat. Methods 2015, 12, 902. [CrossRef] [PubMed]

38. Baggerly, K.A.; Deng, L.; Morris, J.S.; Aldaz, C.M. Differential expression in SAGE: Accounting for normal between-library variation. Bioinformatics 2003, 19, 1477-1483. [CrossRef] [PubMed]

39. Broniek, G.; Langwińska-Wośko, E.; Szaflik, J.; Wróblewska, M. Acinetobacter junii as an aetiological agent of corneal ulcer. Infection 2014, 42, 1051-1053. [CrossRef] [PubMed] 
40. Cydzik-Kwiatkowska, A.; Zielińska, M. Bacterial communities in full-scale wastewater treatment systems. World J. Microbiol. Biotechnol. 2016, 32, 66. [CrossRef] [PubMed]

41. Spies, M.; Kowalczykowski, S.C. Homologous recombination by RecBCD and RecF pathways. In The Bacterial Chromosome 2005; ASM Press: Washington, DC, USA, 2005; pp. 389-403.

42. Dillingham, M.S.; Kowalczykowski, S.C. RecBCD enzyme and the repair of double-stranded DNA breaks. Microbiol. Mol. Biol. Rev. MMBR 2008, 72, 642-671. [CrossRef] [PubMed]

43. Kickstein, E.; Harms, K.; Wackernagel, W. Deletions of recBCD or recD influence genetic transformation differently and are lethal together with a recJ deletion in Acinetobacter baylyi. Microbiology 2007, 153 Pt 7, 2259-2270. [CrossRef] [PubMed]

44. Nair, S.; Finkel, S.E. Dps protects cells against multiple stresses during stationary phase. J. Bacteriol. 2004, 186, 4192-4198. [CrossRef] [PubMed]

45. Boubrik, F.; Rouviere-Yaniv, J. Increased sensitivity to gamma irradiation in bacteria lacking protein, H.U. Proc. Natl. Acad. Sci. USA 1995, 92, 3958-3962. [CrossRef] [PubMed]

46. Li, S.; Waters, R. Escherichia coli strains lacking protein HU are UV sensitive due to a role for HU in homologous recombination. J. Bacteriol. 1998, 180, 3750-3756. [PubMed]

47. Miyabe, I.; Zhang, Q.M.; Kano, Y.; Yonei, S. Histone-like protein HU is required for recA gene-dependent DNA repair and SOS induction pathways in UV-irradiated Escherichia coli. Int. J. Radiat. Biol. 2000, 76, $43-49$. [CrossRef] [PubMed]

48. Knowles, T.J.; Scott-Tucker, A.; Overduin, M.; Henderson, I.R. Membrane protein architects: The role of the BAM complex in outer membrane protein assembly. Nat. Rev. Microbiol. 2009, 7, 206-214. [CrossRef] [PubMed]

49. Knowles, T.J.; Browning, D.F.; Jeeves, M.; Maderbocus, R.; Rajesh, S.; Sridhar, P.; Manoli, E.; Emery, D.; Sommer, U.; Spencer, A.; et al. Structure and function of BamE within the outer membrane and the beta-barrel assembly machine. EMBO Rep. 2011, 12, 123-128. [CrossRef] [PubMed]

50. Ruiz, N.; Falcone, B.; Kahne, D.; Silhavy, T.J. Chemical conditionality: A genetic strategy to probe organelle assembly. Cell 2005, 121, 307-317. [CrossRef] [PubMed]

51. Denks, K.; Vogt, A.; Sachelaru, I.; Petriman, N.-A.; Kudva, R.; Koch, H.-G. The Sec translocon mediated protein transport in prokaryotes and eukaryotes. Mol. Membr. Biol. 2014, 31, 58-84. [CrossRef] [PubMed]

52. Maillard, A.P.; Chan, K.K.Y.; Duong, F. Preprotein translocation through the Sec translocon in bacteria. In Protein Movement Across Membranes; Springer: Boston, MA, USA, 2005; pp. 19-32.

53. Fekkes, P.; Driessen, A.J.M. Protein targeting to the bacterial cytoplasmic membrane. Microbiol. Mol. Biol. Rev. 1999, 63, 161-173. [PubMed]

54. Hunt, M.C.; Siponen, M.I.; Alexson, S.E.H. The emerging role of acyl-CoA thioesterases and acyltransferases in regulating peroxisomal lipid metabolism. Biochim. Biophys. Acta (BBA) 2012, 1822, 1397-1410. [CrossRef] [PubMed]

55. Fixter, L.M.; Nagi, M.N.; Mccormack, J.G.; Fewson, C.A. Structure, distribution and function of wax esters in Acinetobacter calcoaceticus. Microbiology 1986, 132, 3147-3157. [CrossRef]

56. Kalscheuer, R.; Steinbuchel, A. A novel bifunctional wax ester synthase/acyl-CoA:diacylglycerol acyltransferase mediates wax ester and triacylglycerol biosynthesis in Acinetobacter calcoaceticus ADP1. J. Biol. Chem. 2003, 278, 8075-8082. [CrossRef] [PubMed]

57. Ishige, T.; Tani, A.; Sakai, Y.; Kato, N. Wax ester production by bacteria. Curr. Opin. Microbiol. 2003, 6, 244-250. [CrossRef]

58. Chaiyen, P.; Suadee, C.; Wilairat, P. A novel two-protein component flavoprotein hydroxylase. Eur. J. Biochem. 2001, 268, 5550-5561. [CrossRef] [PubMed]

59. Choudhary, S.; Sar, P. Real-time PCR based analysis of metal resistance genes in metal resistant Pseudomonas aeruginosa strain J007. J. Basic Microbiol. 2016, 56, 688-697. [CrossRef] [PubMed]

60. Monsieurs, P.; Moors, H.; Van Houdt, R.; Janssen, P.J.; Janssen, A.; Coninx, I.; Mergeay, M.; Leys, N. Heavy metal resistance in Cupriavidus metallidurans $\mathrm{CH} 34$ is governed by an intricate transcriptional network. Biometals 2011, 24, 1133-1151. [CrossRef] [PubMed]

61. Shi, P.; Jia, S.; Zhang, X.X.; Zhang, T.; Cheng, S.; Li, A. Metagenomic insights into chlorination effects on microbial antibiotic resistance in drinking water. Water Res. 2013, 47, 111-120. [CrossRef] [PubMed] 
62. Karumathil, D.P.; Yin, H.-B.; Kollanoor-Johny, A.; Venkitanarayanan, K. Effect of chlorine exposure on the survival and antibiotic gene expression of multidrug resistant Acinetobacter baumannii in Water. Int. J. Environ. Res. Public Health 2014, 11, 1844-1854. [CrossRef] [PubMed]

63. Kohanski, M.A.; DePristo, M.A.; Collins, J.J. Sublethal antibiotic treatment leads to multidrug resistance via radical-induced mutagenesis. Mol. Cell 2010, 37, 311-320. [CrossRef] [PubMed]

64. Bogomolnaya, L.M.; Andrews, K.D.; Talamantes, M.; Maple, A.; Ragoza, Y.; Vazquez-Torres, A.; Andrews-Polymenis, H. The ABC-type efflux pump MacAB protects Salmonella enterica serovar typhimurium from oxidative stress. mBio 2013, 4, e00630-13. [CrossRef] [PubMed]

65. Rumbo-Feal, S.; Gómez, M.J.; Gayoso, C.; Álvarez-Fraga, L.; Cabral, M.P.; Aransay, A.M.; Rodríguez-Ezpeleta, N.; Fullaondo, A.; Valle, J.; Tomás, M.; et al. Whole transcriptome analysis of Acinetobacter baumannii assessed by RNA-sequencing reveals different mRNA expression profiles in biofilm compared to planktonic cells. PLoS ONE 2013, 8, E72968. [CrossRef] [PubMed]

66. Cray, J.A.; Bell, A.N.; Bhaganna, P.; Mswaka, A.Y.; Timson, D.J.; Hallsworth, J.E. The biology of habitat dominance; can microbes behave as weeds? Microb. Biotechnol. 2013, 6, 453-492. [CrossRef] [PubMed]

67. Balaban, N.Q.; Merrin, J.; Chait, R.; Kowalik, L.; Leibler, S. Bacterial persistence as a phenotypic switch. Science 2004, 305, 1622-1625. [CrossRef] [PubMed]

68. Rittershaus, E.S.; Baek, S.H.; Sassetti, C.M. The normalcy of dormancy: Common themes in microbial quiescence. Cell Host Microbe 2013, 13, 643-651. [CrossRef] [PubMed]

69. Shaikh, A.S.; Tang, Y.J.; Mukhopadhyay, A.; Martin, H.G.; Gin, J.; Benke, P.I.; Keasling, J.D. Study of stationary phase metabolism via isotopomer analysis of amino acids from an isolated protein. Biotechnol. Prog. 2010, 26, 52-56. [CrossRef] [PubMed]

70. Klappenbach, J.A.; Dunbar, J.M.; Schmidt, T.M. rRNA operon copy number reflects ecological strategies of bacteria. Appl. Environ. Microbiol. 2000, 66, 1328-1333. [CrossRef] [PubMed]

71. Mahillon, J.; Chandler, M. Insertion sequences. Microbiol. Mol. Biol. Rev. MMBR 1998, 62, 725-774. [PubMed]

72. Mugnier, P.D.; Poirel, L.; Nordmann, P. Functional analysis of insertion sequence ISAba1, responsible for genomic plasticity of Acinetobacter baumannii. J. Bacteriol. 2009, 191, 2414-2418. [CrossRef] [PubMed]

73. Smith, M.G.; Gianoulis, T.A.; Pukatzki, S.; Mekalanos, J.J.; Ornston, L.N.; Gerstein, M.; Snyder, M. New insights into Acinetobacter baumannii pathogenesis revealed by high-density pyrosequencing and transposon mutagenesis. Genes Dev. 2007, 21, 601-614. [CrossRef] [PubMed]

74. Rose, A. TnAbaR1: A novel Tn7-related transposon in Acinetobacter baumannii that contributes to the accumulation and dissemination of large repertoires of resistance genes. Biosci. Horiz. 2010, 3, 40-48. [CrossRef]

75. Mussi, M.A.; Limansky, A.S.; Viale, A.M. Acquisition of resistance to carbapenems in multidrug-resistant clinical strains of Acinetobacter baumannii: Natural insertional inactivation of a gene encoding a member of a novel family of beta-barrel outer membrane proteins. Antimicrob. Agents Chemother. 2005, 49, 1432-1440. [CrossRef] [PubMed]

76. Heritier, C.; Poirel, L.; Nordmann, P. Cephalosporinase over-expression resulting from insertion of ISAba1 in Acinetobacter baumannii. Clin. Microbiol. Infect. 2006, 12, 123-130. [CrossRef] [PubMed]

77. Block, A.; Alfano, J.R. Plant targets for Pseudomonas syringae type III effectors: Virulence targets or guarded decoys? Curr. Opin. Microbiol. 2011, 14, 39-46. [CrossRef] [PubMed]

78. Peleg, A.Y.; Seifert, H.; Paterson, D.L. Acinetobacter baumannii: Emergence of a successful pathogen. Clin. Microbiol. Rev. 2008, 21, 538-582. [CrossRef] [PubMed]

79. Lee, J.S.; Lee, K.C.; Kim, K.K.; Hwang, I.C.; Jang, C.; Kim, N.G.; Yeo, W.H.; Kim, B.S.; Yu, Y.M.; Ahn, J.S. Acinetobacter antiviralis sp. nov., from tobacco plant roots. J. Microbiol. Biotechnol. 2009, 19, 250-256. [CrossRef] [PubMed]

80. Kang, Y.S.; Jung, J.; Jeon, C.O.; Park, W. Acinetobacter oleivorans sp. nov. is capable of adhering to and growing on diesel-oil. J. Microbiol. 2011, 49, 29-34. [CrossRef] [PubMed]

81. Alvarez-Perez, S.; Lievens, B.; Jacquemyn, H.; Herrera, C.M. Acinetobacter nectaris sp. nov. and Acinetobacter boissieri sp. nov., isolated from floral nectar of wild Mediterranean insect-pollinated plants. Int. J. Syst. Evolut. Microbiol. 2013, 63 Pt 4, 1532-1539. [CrossRef] [PubMed]

(C) 2018 by the authors. Licensee MDPI, Basel, Switzerland. This article is an open access article distributed under the terms and conditions of the Creative Commons Attribution (CC BY) license (http://creativecommons.org/licenses/by/4.0/). 